\title{
CARBONO, NITROGÊNIO E BIOMASSA MICROBIANA DO SOLO EM UMA CRONOSSEQUÊNCIA FLORESTA-PASTAGEM EM PARAGOMINAS, PARÁ (AMAZÔNIA ORIENTAL).
}

\section{ANA PAUla De ARRUda Geraldes}

Bióloga

Orientador: Prof. Dr. Carlos C. Cerri

Dissertação apresen tada à Escola Superior de Agricultura "Luiz de Queiroz", da Universidade de São Paulo, para obtenção do título de Mestre em Agronomia, Área de Concentração: Microbiologia Agrícola.

PIRACICABA

Estado de São Paulo - Brasil

Agosto -1993 
CARBONO, NITROGÊNIO E BIOMASSA MICROBIANA DO SOLO EM UMA CRONOSSEQUÊNCIA FLORESTA-PASTAGEM EM PARAGOMINAS, PARÁ (AMAZÔNIA ORIENTAL).

\section{ANA PAUla de ARRUda Geraldes}

Aprovada em: 25/10/1993

Comissão Julgadora:

Prof. Dr. Carlos Clemente Cerri............CENA/USP

Prof. Dr. Wanderley José de Mello............UNESP/JABOTICABAL

Profa. Dra. Siu Mui Tsai...........................ENA/USP

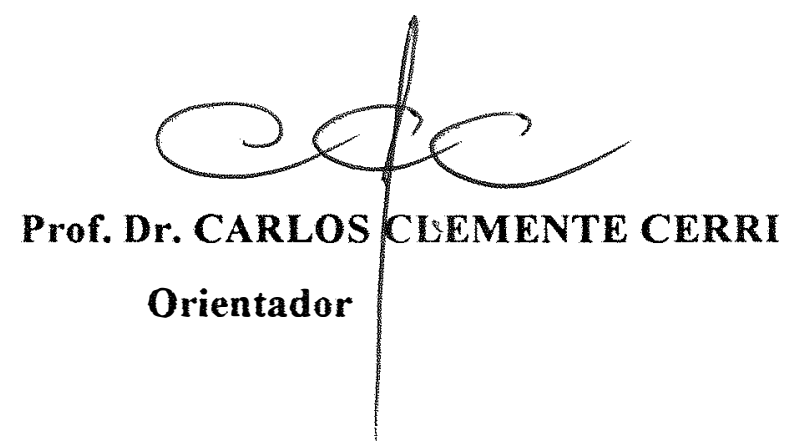


AO MEU MARIDO SERGIO,

POR TODAS AS HORAS ROUBADAS.

OFEREÇO

AOS MEUS PAIS, POR TORNAREM ISTO

UMA REALIDADE.

\section{DEDICO}




\section{AGRADECIMENTOS}

Agradeço a todos que comigo participaram desta realização e em especial:

Ao meu orientador, Dr.Carlos C. Cerri, pela orientação, experiência e amizade, fundamentais para a realização deste abalho.

A Dra. Brigitte P. Eduardo pelos esclarecimentos, críticas e sugestões.

Ao José Roberto Martins pelos valiosos ensinamentos no laboratório.

A Mara Piacentini e Sandra Nicolete pela amizade e carinho com que fui recebida.

Aos amigos da Seção Qímica do Solo: Marisa Piccolo, Jener F. L. de Moraes, Martial Bernoux, Dacir Bortoleto e Marciano pelo auxílio prestado. 


\section{SUMÁRIO}

\section{Página}

LISTA DAS FIGURAS ....................................................... viii

LISTA DAS TABELAS.................................................... $\mathrm{x}$

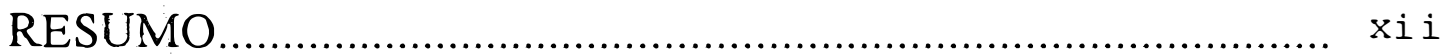

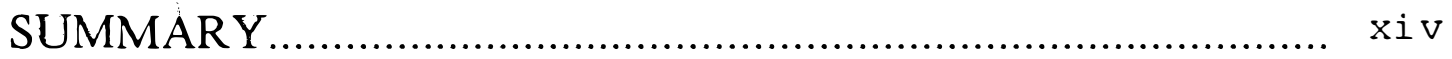

1.INTRODUÇÃ O............................................................ I

2.REVISÃO DE LITERATURA............................................. 4

2.1. Importância da matéria orgânica do solo......................... 4

2.2. Estoque de carbono e nitrogênio total em áreas naturais.. 5

2.3. Alterações e origem do conteúdo de carbono em consequência do cultivo............................................... 8

2.3.1. Uso de isótopos.............................................. 9

2.3.2. Resultados de pesquisas com utilizaçãode isótopos. 10

2.4. Biomassa microbiana do solo...................................... 11

2.4.1. Definição e importância......................................... 11

2.4.2. Métodos de estudo............................................... 12

2.4.3. Consequências do manejo do solo sobre a biomassa microbiana.............................................. 14

3. MATERIAL E MÉTODOS............................................... 17

3.1. Descrição da área.................................................... 17

3.1.1. Características da Cronossequência........................ 18

3.2. O solo...................................................................... 19 
3.2.1. Caracterização...................................................... 19

3.2.2. Amostragem....................................................... 21

3.2.3. Preparação das amostras.......................................... 21

3.3. Determinação da densidade do solo.................................. 22

3.4. Determinação do estoque de carbono total.......................... 22

3.5. Determinação da origem da matéria orgânica do solo.. 23

3.5.1. Determinação do carbono proveniente da pastagem e remanescente da floresta...................................... 23

3.5.2. Determinação do Carbono estável e biodegradável.. 24

3.6. Determinação do estoque de nitrogênio total.......................... 25

3.7. Estimativa da biomassa microbiana.................................... 25

3.7.1. Estimativa da biomassa microbiana $C$ pelo método da fumigação-incubação......................................... 25

3.7.2. Estimativa da biomassa microbiana $C$ pelo método da fumigação-extração............................................. 26

3.7.3. Estimativa da biomassa microbiana $\mathrm{N}$ pelo método da fumigação-extração............................................. 27

4. RESULTADOS E DISCUSSÃO.......................................... 30

4.1. Distribuição do carbono e nitrogênio do solo........................ 30

4.2. Conteúdo de carbono do solo.............................................. 33

4.3. Constituição isotópica da matéria orgânica dos solos sob mata natural e pastagens................................................ 37

4.4. Modificações na qualidade da matéria orgânica do solo devido à implantação de pastagens....................................... 38

4.4.1. Carbono estável e biodegradável derivado da floresta.............................................. 41 
4.5. Conteúdo de nitrogênio do solo..................................... 43

4.6. A estimativa da biomassa mirobiana $\mathrm{C}$ pelos métodos da Fumigação-Incubação e Fumigação-Extração........................ 47

4.7. Estimativa da biomassa microbiana N.................................. 53

4.8. Relação entre carbono total, nitrogênio total e biomassa

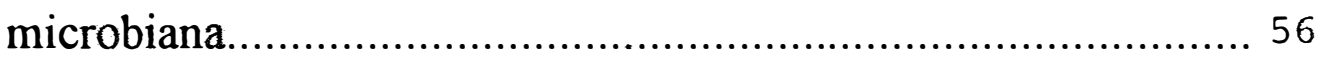

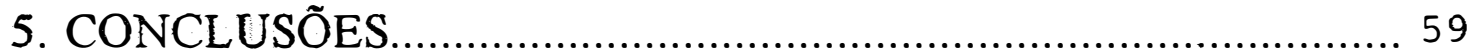

6. LITERATURA CITADA..................................................... 61 


\section{LISTAS DAS FIGURAS}

Página

Figura 01 - Localização da área estudada........................ 18

Figura 02 - Esquema do método da Fumigação-Incubação de JENKINSON \& POWLSON (1976)........ 28

Figura 03 - Esquema do método da Fumigação-Extração de VANCE et al. (1987)............................ 29

Figura 04 - Carbono total acumulado no solo das áreas de mata natural e pastagens................................ 35

Figura 05 - Distribuição dos valores de $\delta^{13} \mathrm{C}$ das áreas de pastagem e mata natural............................... 38

Figura 06 - Porcentagem de variação do $C$ total, carbono da floresta e carbono da pastagem em função do tempo de cultivo a $30 \mathrm{~cm}$ de profundidade. 40

Figura 07 - Representação da quantidade do carbono total da floresta $(\mathrm{Cft})$, carbono da floresta estável (Cfe) e carbono da floresta biodegradável (Cfb) em função do tempo de cultivo a $30 \mathrm{~cm}$ de profundidade............................................ 42

Figura 08 - Esquema das quantidades de carbono da floresta estável biodegradável e do carbono proveniente da pastagem na camada de de $30 \mathrm{~cm}$

Figura 09 - Nitrogênio total acumulado no solo das áreas 
de mata natural e pastagens.............................. 46

Figura 10 - Biomassa microbiana $\mathrm{C}$ determinada pelo método FI....................................................... 49

Figura 11 - Biomassa microbiana $\mathrm{C}$ determinada pelo método FE...................................................... 51

Figura 12 - Relação entre a biomassa microbiana estimada pelo método da FI e o fluxo de carbono extraído pelo método da FE................ 52

Figura 13 - Biomassa microbiana $\mathrm{N}$ determinada pelo método FE........................................................ 55 


\section{LISTA DE TABELAS}

\section{Página}

Tabela 01 - Características do solo................................ 20

Tabela 02 - Distribuição da porcentagem de carbono e nitrogênio e densidade do solo................... 31

Tabela 03 - Conteúdo de carbono do solo (t/ha) das áreas de pastagens e mata natural............ 34

Tabela 04 - Origem do carbono do solo sob pastagens de 4,10 e 5 anos de implantação. Carbono da floresta (Cf), carbono da pastagem (Cp)........................................ 39

Tabela 05 - Quantidade de carbono total da floresta (Cf), carbono da floresta biodegradável (Cfb) e carbono da floresta estável (Cfe).....

Tabela 06 - Conteúdo de nitrogênio do solo ( $t / h a)$ das áreas de pastagens e mata natural.................

Tabela 07 - Biomassa microbiana $\mathrm{C}$ determinada pelo método da Fumigação-Incubação.Média de três repetições espaciais................................ 48

Tabela 08 - Biomassa microbiana $\mathrm{C}$ determinada pelo método da Fumigação-Extração. Média de três repetições espaciais.

Tabela 09 - Biomassa microbiana $\mathrm{N}$ determinada pelo método da Fumigação-Extração. Média de três repetições espaciais................................ 54

Tabela 10 - Relação entre carbono total, nitrogênio total 
e biomassa microbiana $\mathrm{C}$ e $\mathrm{N}$ determinada

pelo método FE..................................... 57 


\title{
CARBONO, NITROGÊNIO E BIOMASSA MICROBIANA DO SOLO EM UMA CRONOSSEQUENCIA FLORESTA-PASTAGEM EM PARAGOMINAS, PARÁ (AMAZÔNIA ORIENTAL).
}

\author{
Autora : ANA PAULA DE ARRUDA GERALDES \\ Orientador : Prof. Dr. CARLOS C. CERRI
}

\section{RESUMO}

O presente trabalho foi desenvolvido com o objetivo de quantificar os estoques de carbono, nitrogênio e a biomassa microbiana do solo e as alterações ocorridas durante a transformação de áreas de Floresta tropical amazônica em pastagens.

Solos coletados de áreas com pastagens de 4, 10 e 15 anos e uma mata natural de referência na região de Paragominas - Pará foram analisados quanto ao seu teor de carbono, nitrogênio, constituição isotópica e biomassa microbiana. A biomassa microbiana $\mathrm{C}$ foi estimada através dos métodos de Fumigação-Incubação e Fumigação-Extração e a biomassa microbiana $\mathrm{N}$ somente através do método da Fumigação-Extração.

Com a implantação da pastagem o conteúdo de carbono aumentou ao longo do tempo de cultivo. Após 4 e 15 anos de cultivo o conteúdo de carbono aumentou em 1,6 tC/ha e 3,7 tC/ha na camada 
superficial do solo. A pastagem de 10 anos diminuiu em relação à mata natural, devido ao fato de ter sido cultivada por 2 anos consucutivos com milho antes da implantação.

A matéria orgânica da área sob mata natural era composta de 40,2 tC/ha de carbono estável e 12,2 tC/ha de carbono biodegradável, sendo que após 10 e 15 anos de pastagem o carbono biodegradável representava $7,0 \mathrm{tC} /$ ha e $5,3 \mathrm{tC} / \mathrm{ha}$, correspondendo a $14,8 \%$ e $11,6 \%$ do carbono da floresta e o carbono estável representava $88 \%$ do carbono da floresta.

O conteúdo de nitrogênio aumentou após a introdução da pastagem, sendo maior na pastagem com 4 anos.

A biomassa microbiana concentrou-se na camada superficial do solo e mostrou-se maior na área sob pastagem de 4 anos ; a medida que as pastagens tornaram-se mais velhas a biomassa microbiana diminuiu.

A relação entre o carbono total e a biomassa microbiana C foi maior apenas na pastagem de 4 anos, mas a relação entre o nitrogênio total e a biomassa microbiana $\mathrm{N}$ foi maior em todas as pastagens. 
CARBON, NITROGEN AND SOIL MICROBIAL BIOMASS IN FLOREST-PASTURE CRONOSSEQUENCE IN PARAGOMINAS, PARÁ (EASTERN AMAZON).

Author: ANA PAULA DE ARRUDA GERALDES

Adviser: Prof. Dr. CARLOS C. CERRI

SUMMARY

The present work was developed with the objective of quantify the carbon and nitrogen budget, the soil microbiol biomass and the changes occured while transformation of Amazon tropical florest sites in pastures.

Soils sampled from sites with pastures of 4,10 and 15 years and one reference native florest from Paragominas - Pará, were used to determine the carbon and nitrogen content, the natural abundance of ${ }^{13} \mathrm{C}$ isotope and the microbial biomass. The microbial biomass $C$ was estimate through the Fumigation-Incubation and Fumigation-Extraction methods, and microbial biomass $\mathrm{N}$ through the Fumigation-Extraction method.

Due to the pasture establishment, the carbon content was increased. After 4 and 15 years of culture the carbon content increased 1,6 
$\mathrm{tC} / \mathrm{ha}$ and $3,7 \mathrm{tC} / \mathrm{ha}$ in soil surface layer. The pasture of 10 years deceased $6,8 \%$ in relation to natural florest due to maize cultivation for two years before pasture establishment.

The organic matter under the natural forest site consisted of 40,2 tC/ha of the stable carbon and 12,2 tC/ha of the biodegradabily carbon. After 10 and 15 years under pasture the carbon biodegradable carbon represented 7,0 tC/ha and 5,3 tC/ha, corresponding to $14,8 \%$ and $11,6 \%$ from the florest carbon, the stable carbon represented $88 \%$ from the florest carbon.

The nitrogen contend increased after the pasture establishment being higher in the 4 years pasture.

The microbial biomass concentrated in the soil surface layer and was higher in the 4 years pasture. Microbial biomass decreased according to the pastures ages.

The relation between total carbon and microbial biomass $\mathrm{C}$ was higher only in the 4 years pasture, but the relation between total nitrogen and microbial biomass $\mathrm{N}$ was higher in all the pastures. 


\section{INTRODUÇÃO}

A região de Paragominas-PA, representa uma das áreas mais expressivas de utilização de pastagens na Amazônia. Até 1960, as pastagens eram restritas às áreas naturais, representando cerca de 15.000 $\mathrm{km}^{2}$. FEARNSIDE (1989), em recentes estimativas, verificou que $8 \times 10^{6}$ ha de floresta nativa tem sido cortada e transformada em pastagens, dos quais $3,5 \times 10^{6}$ ha somente em 1987.

A conversão das florestas nativas em áreas de pastagens provoca grandes mudanças na vegetação e propriedades do solo; por isso, o corte das florestas tem sido uma das atividades mais controvertidas em termos de risco potencial para o ecossistema natural da Amazônia.

Na maioria dos casos, com a implantação da pastagem, a produtividade decresce após dois a três anos de cultivo e a fertilidade é recuperada somente vários anos após o abandono da área (MARTINS,1987). Apesar de sua grande exuberância,a Floresta Amazônica 
está estabelecida sobre solos pobres em nutrientes minerais, ficando sua manutenção dependente da ciclagem dos nutrientes contidos na biomassa vegetal. Deste modo, é através da decomposição da matéria orgânica que os nutrientes passam ao meio biótico.

A quantidade de matéria orgânica do solo é geralmente expressa pelo seu conteúdo em carbono ou pelo conteúdo em nitrogênio. $\mathrm{O}$ desmatamento e cultivo leva geralmente a uma redução nos conteúdos de carbono e nitrogênio, dependendo das condições edafoclimáticas e do agrossistema estabelecido.

O reconhecimento da importância dos microrganismos no funcionamento dos ecossistemas tem levado a um crescente interesse em se medir os níveis de nutrientes em sua biomassa e as taxas com que são imobilizados e mineralizados.

A estimativa da biomassa microbiana permite acompanhar muito mais rapidamente as mudanças nas propriedades biológicas do solo decorrentes do manejo, pois reage com maior rapidez que os parâmetros físico-químicos (POWLSON et al.,1987).

Sendo assim, o conhecimento das alterações do conteúdo de carbono e nitrogênio, das origens da matéria orgânica do solo e do comportamento da sua fração microbiana pode ser um valioso instrumento para se entender o ciclo da matéria orgânica e auxiliar na seleção da prática de manejo mais apropriada e eficiente.

O objetivo geral deste trabalho foi o de quantificar os estoques de carbono e nitrogênio e as alterações nestes estoques decorrentes da implantação de pastagens em áreas de Floresta Tropical Amazônica. 
Os objetivos específicos foram:

- Quantificar o carbono remanescente da floresta e o proveniente da pastagem, utilizando técnicas isotópicas.

- Calcular a fração estável e biodegradável do carbono remanescente da floresta.

- Estimar a biomassa microbiana C pelos métodos da Fumigação-Incubação e Fumigação-Extração e a biomassa microbiana $\mathrm{N}$ pelo método da Fumigação-Extração.

- Determinar a relação existente entre a biomassa microbiana $\mathrm{C}$ e $\mathrm{N}$ e o estoque de carbono e nitrogênio.

Para atingir estes objetivos foram colhidas amostras de solos sob floresta e pastagens da região de Paragominas - Pará e analisadas quanto aos teores de carbono, nitrogênio e estimada a biomassa microbiana. 


\section{REVISĀO DE LITERATURA.}

\subsection{Importância da Matéria Orgânica do Solo.}

A decomposição dos resíduos animais e vegetais do solo constitui um processo biológico básico, no qual o carbono é reciclado para a atmosfera na forma de $\mathrm{CO}_{2}$, o nitrogênio se torna disponível como $\mathrm{NH}_{4}^{+}$ e $\mathrm{NO}_{3}^{-}$e outros elementos como $\mathrm{P}, \mathrm{S}$ e vários micronutrientes aparecem nas formas requeridas pelas plantas superiores. Neste processo, parte dos nutrientes é assimilado pelos microrganismos (ORJUELA,1989).

Através dos processos de mineralização, os elementos absorvidos pelas plantas são mineralizados. Contudo, esta mineralização não é completa e uma grande parte destes compostos orgânicos são modificados pelos microrganismos, formando complexos orgânicos resistentes, os quais, junto com os constituintes microbianos e outros produtos resistentes do metabolismo constituem a matéria orgânica do solo.

A matéria orgânica do solo representa um dos materiais mais complexos existentes na natureza, sendo um componente chave para a maioria dos processos microbiológicos que ocorrem nos solos de 
ecossistemas florestais (LUIZÃO \& SCHUBART,1987).

A importância da matéria orgânica aumenta em ecossistema de Floresta Tropical, que apresenta solos pobres em nutrientes e onde a vegetação depende em grande parte da reciclagem de nutrientes contidos nos detritos vegetais (HERRERA et al.,1978).

Outro importante papel da matéria orgânica na fertilidade do solo é através de seus efeitos sobre as propriedades químicas e físicas do solo. Assim, a matéria orgânica aumenta a CTC do solo e, conseqüentemente, a retenção de nutrientes, favorece a absorção de alguns micronutrientes, aumenta a retenção de água, melhora a agregação do solo e diminui o efeito de elementos tóxicos como o alumínio.

\subsection{Estoque de Carbono e Nitrogênio Total em Áreas Naturais}

Através de pesquisas realizadas por vários autores (Buring,1984; Schlesinger,1983; Bohn,1978 citados por MORAES,1991) o conteúdo de carbono do solo estocado mundialmente foi estimado entre 2.000 a $4.000 \times 10^{15} \mathrm{~g}$ de carbono.

Com base em dados de 1950, WOODWELL et al. (1978) estimaram a quantidade total de carbono estocada na biota viva em aproximadamente $830 \times 10^{15} \mathrm{~g}$; deste total, cerca de $461 \times 10^{15} \mathrm{~g}$ estavam estocados nas florestas tropicais, representando $55,5 \%$ do conteúdo total de carbono, e o carbono estocado no humus representava 1.000 a $3.000 \times 10^{15}$ $\mathrm{g}$, sendo superior de um a quatro vezes a quantidade estocada na biota viva.

POST et al. (1982), SCHLESINGER (1977),Brown \& Lugo (1980) citado por HOUGHTON et al. (1983) e HOUGTON et al. 
(1985) quantificaram o conteúdo de carbono estocado nas áreas de florestas tropicais e florestas tropicais úmidas e seus resultados mostram a grande variação que ocorre nas estimativas do estoque de carbono nestas áreas.

Em estimativa do conteúdo de carbono total da América do Sul, BOHN (1976) calculou o estoque de carbono em $301 \times 10^{15} \mathrm{~g}$ de $\mathrm{C}$ a $100 \mathrm{~cm}$ de profundidade.

MORAES (1991), através de informações obtidas pelo Projeto RADAMBRASIL, gerou um banco de dados dos solos da bacia Amazônica, constituído de 5560 horizontes e concluiu que estão estocados de 2,0 a 1,0\% do conteúdo total de carbono dos solos do globo para a profundidade de $100 \mathrm{~cm}$ e que o conteúdo total de carbono dos solos da bacia Amazônica representam 13,6\% do conteúdo total de carbono da América do Sul, estimado por BOHN (1976).

Nos solos da Bacia Amazônica o conteúdo de carbono está acumulado na camada superficial de $0-20 \mathrm{~cm}$, representando $45,6 \%$ do carbono estocado a $100 \mathrm{~cm}$ de profundidade,enquanto que o nitrogênio apresentou $41,8 \%$ do total estocado a $20 \mathrm{~cm}$ de profundidade (MORAES, 1991).

Para TEIXEIRA \& BASTOS (1989), o estoque de carbono no solo, até um metro de profundidade em florestas primárias da Amazônia Central, região de Manaus, é de 148 t/ha. Constata-se que a quantidade de carbono orgânico é bem superior à obtida por MARTINS \& CERRI (1986) na região de Capitão Poço,no Pará, e próximo à encontrada por CHAUVEL (1982) na região de Manaus. O nitrogênio total do solo, a uma profundidade de $100 \mathrm{~cm}$, foi estimado em $11,087 \mathrm{Kg} / \mathrm{ha}$, representando $77,2 \%$ do estoque total de nitrogênio na floresta primária $(14,367 \mathrm{Kg} / \mathrm{ha})$. 
Estimativas do conteúdo de carbono e nitrogênio total foram realizadas por CHONE et al. (1991) em duas áreas de latossolo amarelo localizada perto de Manaus, na Amazônia Central, sedo que o estoque de carbono correspondeu a 66,0 tha e 90 tha e o nitrogênio à 5,2 t/ha e 6,5 tha de $\mathrm{N}$ nos $20 \mathrm{~cm}$ superficiais do solo. CERRI (1989) quantificou o conteúdo total de carbono em Latossolos amarelos da região de Manaus, nos $20 \mathrm{~cm}$ superficiais, em 90 tha.

MARTINS et al. (1990b) quantificaram o estoque de carbono nos $100 \mathrm{~cm}$ superficiais do solo em latossolos amarelos na Amazônia Oriental (Capitão Poço - Pará) em 65,7 tha; enquanto que, DESJARDINS et al. (1991), em estudo sobre a distribuição do carbono e nitrogênio na Amazônia Central (Manaus) e Amazônia Oriental (Capitão Poço), estimaram o estoque de carbono e nitrogênio nestas áreas em $86 \mathrm{t} / \mathrm{ha}$ de C e 6,5 t/ha de $N$ e 31 t/ha de $C$ e 3,1 t/ha de $N$.

NEILL et al. (1993, no prelo) estimaram o estoque de carbono total em ecossistemas da bacia Amazônica, na região de Ouro Preto - Rondônia, em 172,0 a 185,0 t/ha sob podzólico vermelho-amarelo e 197,0 a 210,1 tha sob podzólico vermelho-escuro, sendo que 52,0 t/ha e 77,0 tha correspondiam, respectivamente, ao conteúdo de carbono total do solo no podzólico vermelho-amarelo e podzólico vermelho-escuro. $O$ estoque de nitrogênio total do solo foi estimado em 4,2 t/ha e 5,9 t/ha para podzólico vermelho-amarelo e Podzólico vermelho-escuro, correspondendo entre 70 a $72 \%$ e 76 a $78 \%$ do estoque total de nitrogênio do ecossistema. 


\subsection{Alterações e Origem do Conteúdo de Carbono em Consequência do Cultivo.}

O desmatamento e cultivo de áreas naturais provocam alterações no estoque da matéria orgânica; estas alterações são dependentes das condições do solo, clima, tipo de cultura e práticas agrícolas empregadas.

MARTELL \& PAUL (1974); MANN(1986); CERRI \& ANDREUX (1990), realizando trabalhos em solos cultivados, observaram que o cultivo após o desmatamento é frequentemente responsável por uma redução nos conteúdos de carbono e nitrogênio.

Com a finalidade de verificar as modificações decorrentes do desmatamento e do cultivo sobre a matéria orgânica da parte superior do perfil de um ecossistema de "terra firme" na Amazônia Oriental, MARTINS et al. (1990a) estudaram áreas próximas submetidas à queimada, ao cultivo e ao pousio, tendo como base à comparação as condições naturais e verificaram que a quantidade de carbono na camada $0-15 \mathrm{~cm}$ diminuiu após a queimada e continua a diminuir nos solos cultivados por 1 e 5 anos, porém aumentou novamente em conseqüência do pousio.

Em áreas de latossolo amarelo, onde coexistem mata natural e pastagens implantadas há 2 e 8 anos na região de Manaus, o conteúdo de carbono na camada $0-20 \mathrm{~cm}$ da área sob pastagem de 2 anos apresentou um decréscimo de 21,2 tC/ha quando comparado com a mesma camada na mata natural,correspondendo a uma diminuição de $25 \%$ do carbono original. Já na área com 8 anos, o conteúdo de carbono nos primeiros vinte centímetros iniciais ultrapassou em $6 \mathrm{tC} / \mathrm{ha}$ àquele sob mata 
natural (CERRI,1989).

\subsubsection{Uso de Isótopos.}

Nos ecossistemas naturais, o carbono orgânico do solo é proveniente exclusivamente dos resíduos vegetais de suas plantas, enquanto que em agrossistemas o carbono apresenta duas origens: uma remanescente da vegetação nativa e outra produzida pela decomposição dos resíduos vegetais de suas plantas.

A discriminação e quantificação destas duas entradas de matéria orgânica tornou-se possível através de técnicas isotópicas baseadas na abundância natural do ${ }^{13} \mathrm{C}$, onde o $\delta^{13} \mathrm{C}$ da matéria orgânica do solo é derivado da cobertura vegetal que a constituiu e a substituição desta vegetação pode provocar mudanças na composição isotópica da matéria orgânica. Considerando que a matéria orgânica do solo sob floresta consiste de duas frações, a biodegradável e a estável, é possivel estimar, a partir do carbono nativo da floresta, a quantidade de carbono da floresta biodegradável e a quantidade de carbono da floresta estável com o decorrer do tempo de cultivo (CERRI et al.,1985a).

Para o emprego desta metodologia, são necessárias algumas condições específicas: os perfis do solo devem ser homogênios com variações mínimas entre um perfil e outro; o cultivo do solo com determinada cultura deve ser contínuo e a vegetação nativa e a cultura devem possuir ciclos fotossintéticos diferentes. 


\subsubsection{Resultados de Pesquisas com Utilização de Isótopos}

CERRI (1986), estudando as alterações no conteúdo de carbono do solo devido ao cultivo intensivo com cana-de-açúcar na região de Piracicaba, demonstrou que, em cinquenta anos de cultivo, 55\% do carbono era remanescente da floresta $(21,2 \mathrm{t} / \mathrm{ha})$ e $45 \%$ do carbono era originário da cana-de-áçúcar (17,3 tha); e que o compartimento orgânico biodegradável desaparece quase que completamente após 50 anos de cultivo, sendo que $30 \%$ do carbono do solo é representado pela quantidade de carbono estável.

$\mathrm{Na}$ região de Manaus, em áreas sob mata natural e pastagens com 2 e 8 anos de implantação, o carbono originário da pastagem representa $20 \%$ do carbono total do solo após 2 anos de pastagem e $45,8 \%$ após 8 anos. Conseqüentemente, a diminuição do conteúdo de carbono originário da floresta foi de $38 \%$ após 2 anos do desmatamento e de $42,5 \%$ após 8 anos. Do total de $90 \mathrm{tC} /$ ha existentes na mata natural, $50 \mathrm{tC} / \mathrm{ha}$ era constituído de matéria orgânica estável e 40 tCha de matéria orgânica biodegradável, significando que a matéria orgânica remanescente do solo sob floresta na área sob pastagem de 8 anos era constituida quase exclusivamente de carbono estável (CERRI,1989).

Estudos sobre a dinâmica da matéria orgânica em sistemas de floresta-pastagens foram desenvolvidos na região de Ouro Preto do Oeste-RO, em duas cronosseqüências, sendo uma sob podzólico vermelho-escuro (cronosseqüência 1) e outra sob podzólico vermelhoamarelo (cronosseqüência 2); a cronosseqüência 1 constou de uma área de floresta nativa e pastagens com 8 e 20 anos e a cronosseqüência 2 de 
floresta nativa e pastagens com 3,8 e 20 anos. Observou-se que, após 8 anos de uso do solo com pastagem $18 \%$ do carbono do solo era proveniente da pastagem sob podzólico vermelho-amarelo e apenas $9 \%$ era proveniente da pastagem sob podzólico vermelho-escuro;o conteúdo inicial de carbono (1682 t/ha) foi recuperado e superado apenas no podzólico vermelhoamarelo após 20 anos de cultivo em 14\% (192,7 t/ha) (CERRI \& MORAES, 1992).

No que diz respeito às mudanças decorrentes da alteração do ecossistema florestal,verifica-se que o uso e manejo do solo alteram não só a quantidade, mas também a qualidade da matéria orgânica do solo e que a eliminação de um ecossistema natural inicia um processo de mineralização da matéria orgânica biodegradável, o que ocasiona uma redução no estoque de carbono nos primeiros anos após o desmatamento; com a implantação de um sistema de cultivo, o estoque de carbono tende a ser recuperado ao longo do tempo, variando de acordo com as propriedades físicas e químicas de cada solo.

\subsection{Biomassa microbiana do solo.}

\subsubsection{Definição e Importância.}

A biomassa microbiana foi definida por JENKINSON \& LADD (1981) como sendo a parte viva da matéria orgânica do solo, excluindo raízes e animais maiores que $5 \times 10^{-15} \mathrm{~m}^{2}$ e apresenta papel fundamental na manutenção e produtividade de ecossistemas devido aos processos de decomposição realizado pelos microrganismos e a conseqüente mineralização da fração orgânica. 
Constitui um meio de transformação para todos os materias orgânicos do solo e atua como reservatório de nutrientes disponíveis às plantas. O reconhecimento da importância dos microrganismos do solo tem levado a um aumento no interesse em se medir os nutrientes contidos em suas biomassas, cuja estimativa fornece dados úteis sobre mudanças nas propriedades biológicas do solo decorrentes do uso.

A facilidade do método da fumigação-incubação (JENKINSON \& POWLSON,1976), que consiste em tornar os microrganismos susceptíveis à mineralização pela fumigação com vapores de clorofórmio e a subseqüente medida dos constituintes liberados no solo incubado, tem permitido estimativas da biomassa microbiana do solo em uma variedade de ecossistemas.

\subsubsection{Métodos de Estudo.}

Com o crescente aumento do interesse em se estudar a biomassa microbiana dos solos, varios métodos foram sendo desenvolvidos, contudo a confiabilidade destes métodos tem sido amplamente questionada, um vez que a estimativa da biomassa microbiana pode ser afetada pelas condições edafoclimáticas.

Os mais utilizados na quantificação da biomassa microbiana têm sido o método da Fumigação-Incubação (JENKINSON \& POLSON, 1976), método da Fumigação-Extração (BROOKES et al., 1985; VANCE et al.,1987), método da taxa de respiração em resposta a adição de glucose (ANDERSON \& DOMSCH,1978) e método do índice de ATP (OADES \& JENKINSON, 1979). 
Entretanto um dos problemas em se aplicar o método FI (Fumigação-Incubação) nos solos da Amazônia é devido ao pH baixo, onde as populações recolonizadoras das amostras fumigadas não metabolizam tão rapidamente quanto as populações nativas das amostras não fumigadas, ocasionando uma subestimativa da biomassa existente (JENKINSON et al. ,1976; VANCE et al.,1987). Uma alternativa para evitar este problema foi proposta por Paul \& Voroney (1980), citado por SPARLING (1990),onde se utiliza a respiração de solos fumigados entre 10-20 dias.

ROSS (1987) observou que o método FI não é confiável quando aplicado em solos úmidos e compactos. SPARLING \& WEST (1989) recomendam uma correção da umidade à $50 \%$ da capacidade de campo antes da fumigação, visto que o conteúdo de água do solo influencia a estimativa da biomassa microbiana.

Afim de superar as limitações do método FI em solos ácidos e com recentes adições de matéria orgânica, VANCE et al. (1987) desenvolveram o método da fumigação-extração $(\mathrm{FE})$. Neste método, o $\mathrm{C}$ orgânico é extraído das amostras fumigadas e não fumigadas e os nutrientes microbianos são medidos após oxidação química ou digestão.Este método tem sido usado para estimar a biomassa microbiana C, N, P e S. As vantagens do método são a rapidez da análise; evita a mineralização microbiana, a reinoculação e a escolha de um controle apropriado para calcular o fluxo (SPARLING,1990). OCIO \& BROOKES (1990) obtiveram correlações significativas entre o método FE e o índice de ATP em solos onde houve recente adição de matéria orgânica.

Os métodos FI e FE foram analisados em solos da região Amazônica e obteve-se uma correlação positiva entre eles $(r=0,95 \mathrm{P}<0,01)$, 
contudo o $\mathrm{FE}$ apresentou resultados com coeficiente de variação menores, mostrando-se mais eficiente (PFENING et al.,1992).Amostras de solos podzólicos vermelho-amarelo e planossolo em Itaguaí - RJ, foram usadas na comparação dos métodos FI e FE obtendo-se também correlação positiva ( $\mathrm{r}$ $=0,66, \mathrm{P}<0,01)$ e coeficiente de variação menor para o método $\mathrm{FE}$ (RODRIGUES, 1992).

A biomassa microbiana representa um compartimento dinâmico do solo e está sujeita a influências das condições experimentais utilizadas durante sua condução (ROSS et al.,1980). Este aspecto reforça a necessidade de se aplicar mais de um método na estimativa da biomassa microbiana dos solos.

\subsubsection{Consequências do manejo do solo sobre a biomassa microbiana.}

A biomassa microbianaa do solo responde muito mais rapidamente às mudanças de uso e manejo do solo, que representam uma alteração no aporte anual de material argânico para o solo, que os parâmetros físico-químicos (POWLSON et al.,1987).BAUER \& BLACK (1981); GUPTA \& GERMIDA (1988) e SRIVASTAVA \& SINGH (1989) observaram que cultivos realizados em áreas que suportavam vegetação natural levaram a uma considerável perda da matéria orgânica e da biomassa microbiana no solo.

BOTTNER et al. (1988) observaram uma pequena quantidade de biomassa microbiana em solos cultivados durante os primeiros 150 dias e um aumento da biomassa nos períodos posteriores. 
KLEMEDTSSON et al. (1987) não detectaram mudanças significativas na biomassa microbiana $\mathrm{C}$ quando os solos foram cultivados com cevada.

Estimativas da biomassa microbiana em latossolos da Amazônia mostraram que, nas condições de mata natural, a biomassa concentra-se nos primeiros $5 \mathrm{~cm}$ do solo.A derrubada e queima da floresta ocasionou uma queda drástica na biomassa microbiana e uma inversão da sua distribuição com a profundidade (CERRI et al.,1985b; PFENNING et al.,1992).

LUIZÃO (1989), em estudos sob pastagens implantadas com até 4 anos, mostrou que há uma fase de aparente recuperação da biomassa microbiana. No entanto, apesar da quantidade equivalente de biomassa microbiana entre a floresta e as pastagens, a crescente compactação do solo, causada pelo pisoteio pode afetar a intensidade e qualidade da atividade da microflora e fauna devido à diminuição da aeração e oxigenação; e a biomassa microbiana, em termos de porcentagem de carbono total do solo, corresponde a $4 \%$ na floresta, $1,9 \%$ na queimada e $3,8 \%$ na pastagem.

Em pastagens com mais de 5 anos de cultivo, na região de Manaus, onde o solo apresentava-se compactado, os níveis de biomassa microbiana registrados na camada superficial do solo foram quase sempre iguais ou inferiores à metade dos valores encontrados na floresta (BONDE \& ROBERTSON,1991).

CERRI et al. (1985b) quantificaram a biomassa microbiana de um latossolo amarelo distrófico da região Amazônica (Capitão Poço PA) em condições de mata natural, mata recém queimada e capoeira de 3 anos. Seus resultados mostram que, sob condições de mata natural, a biomassa microbiana está restrita aos $15 \mathrm{~cm}$ superficiais do solo e equivale 
a $26 \mathrm{mgC} / \mathrm{m}^{2}$, ou seja, $1,3 \%$ do carbono total. O desmatamento e a queima da vegetação ocasionou queda de $2 / 3$ da biomassa inicial,desaparecendo nos primeiros $10 \mathrm{~cm}$. Na capoeira, a biomassa microbiana reaparecem desde a superficie até $30 \mathrm{~cm}$ de profundidade.

LUIZÃO et al. (1991), estudando o efeito da idade e do manejo das pastagens da Amazônia Central sobre a biomassa microbiana do solo, concluiram que a biomassa microbiana da camada superficial $(0-5 \mathrm{~cm})$ de uma pastagem com 5 anos de utilização foi muito maior que a de uma pastagem com 12 anos e a de uma capoeira com 4 anos. Na camada 5$20 \mathrm{~cm}$, a biomassa microbiana da pastagem mais jovem foi reduzida à metade, quando comparada com sua camada superficial, enquanto que, nas outras áreas, não houve redução significativa.

Contudo, ainda existem poucas informações sobre mudanças no conteúdo da biomassa microbiana durante a transformação da floresta em pastagem e sua distribuição no perfil do solo e a rápida conversão das florestas tropicais demonstram a necessidade de estudos sobre os ciclos dos nutrientes nestes ecossistemas, os quais auxiliarão na resolução dos problemas de manejo do solo. 


\section{MATERIAL E MÉTODOS.}

\subsection{Descrição da Área.}

As áreas estudadas localizam-se na Fazenda Bosque ( $3^{\circ} 05^{\prime} \mathrm{S}$ e $47^{\circ} 24 \cdot \mathrm{W}$ ), situada a $10 \mathrm{Km}$ ao norte do município de Paragominas, Estado do Pará, pela estrada PA-125, distante $1 \mathrm{Km}$ da Br-010.(Figura 01).

A fazenda é composta por cerca de 40 parcelas de pastagens ou de culturas anuais. Nas pastagens encontram-se: Quicuio (Brachiaria humidicola), Colonião (Panicum maximun), Brachiarão (Brachiaria brizantha) e Andropogon (Andropogon gayanus). As culturas anuais são: Soja, Quiabo e Milho.

A mata natural de referência encontra-se ao lado da BR010, distante 1,5 Km da bifurcação com a PA-125.

O clima é do tipo Am, segundo a classificação de Köppen, que define um regime pluviométrico anual com uma estação seca entre Julho e Setembro (VIEIRA \& SANTOS,1987) A temperatura média anual é de $27,9^{\circ} \mathrm{C}$ e a umidade relativa média é de $76 \%$ ao ano, com variação de $71 \%$ no mês de Novembro a $80 \%$ nos meses de Fevereiro a Abril, mostrando, assim, suficiente umidade relativa, durante $o$ ano todo, para a manutenção das pastagens. A vegetação natural que recobre a área ainda não cultivada é a floresta tropical úmida que foi classificada fela FAO com 
floresta sempre verde, cuja característica é possuir copagem bem separadas,e as camadas de arbustos e plantas herbáceas relativamente separadas (FALESI,1976).

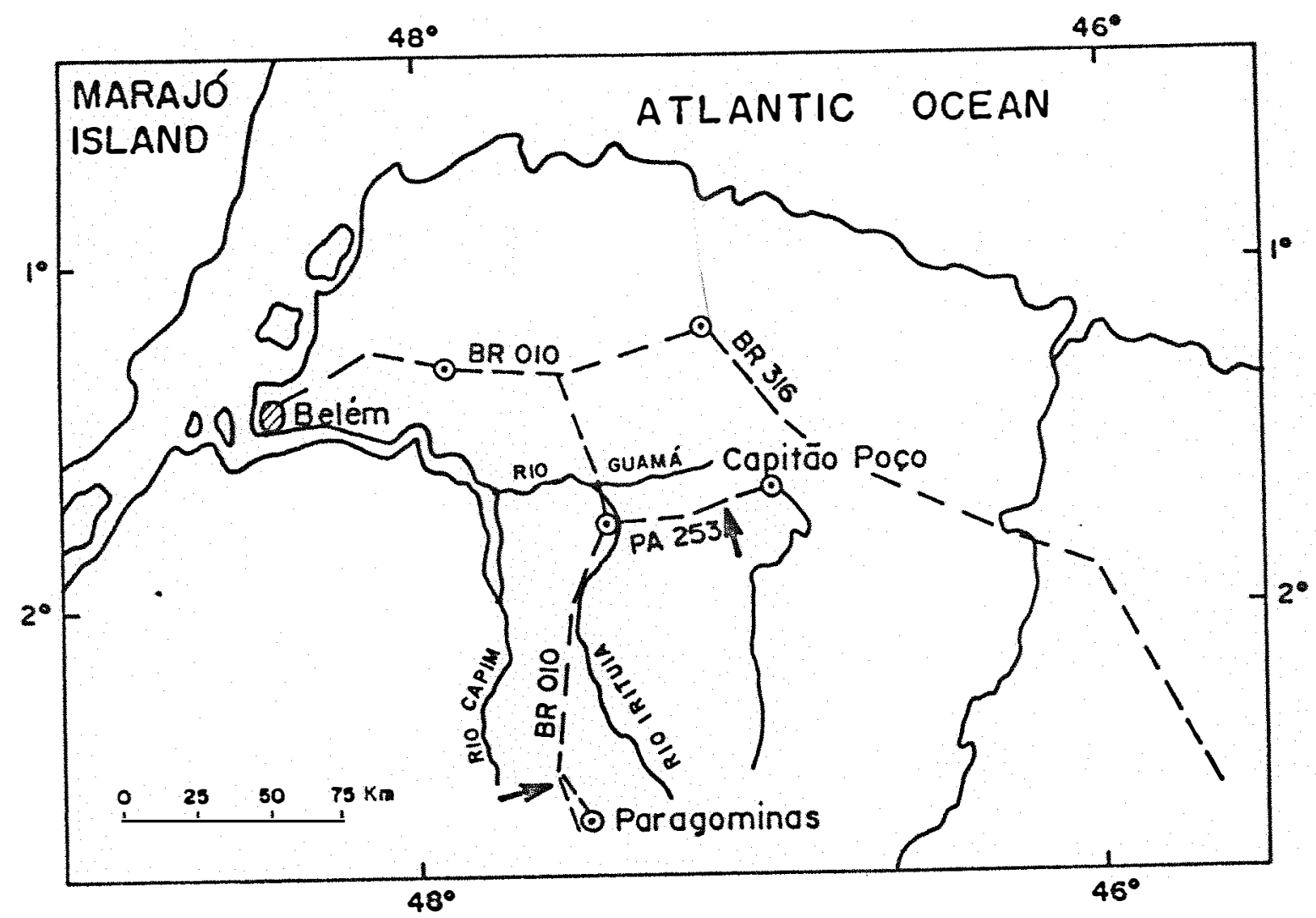

Figura 01 - Localização da área estudada.

\subsubsection{Características da Cronosseqüência.}

$\mathrm{Na}$ área sob pastagem com 15 anos, a floresta foi derrubada em 1975 e a pastagem implantada no início de 1976 após a queima. Esta área foi destocada mecanicamente e adubada com fosfato entre 1980-1981 e cultivada durante um ano (1981-1982) com milho; em seguida 
foi novamente adubada e plantada com capim Colonião e Quicuio. Atualmente há o predominio de Quicuio,porém este apresenta-se pouco desenvolvido.

A área com 10 anos de implantação foi derrubada mecanicamente em 1980, queimada e cultivada com milho durante dois anos consecutivos (1981-1983). Após este período houve uma primeira fertilização e plantou-se capim Colonião. Uma segunda adubação foi realizada após o plantio com $300 \mathrm{Kg} / \mathrm{ha}$ de hiperfosfato. A pastagem foi renovada entre 1991 e 1993 e atualmente encontra-se com Colonião alto e denso e algumas leguminosas.

A área sob pastagem com 4 anos foi derrubada manualmente em 1986, queimada e plantada com capim Colonião e Brachiarão. Não sofreu nenhuma fertilização. Esta pastagem foi destocada mecanicamente em 1991 e atualmente assemelha-se a uma juquira, onde encontram-se Brachiarão pouco denso acompanhado de plantas invasoras.

\subsection{O Solo.}

\subsubsection{Caracterização.}

O tipo de solo predominamte nesta área é o latossolo vermelho amarelo distrófico muito argiloso (LVAd) segundo a classificação brasileira. As característcas dos solos encontran-se na Tabela 01. 
Tabela 01 - Características dos solos. (S: Soma de Bases, V: Saturação de bases)

\begin{tabular}{|c|c|c|c|c|c|c|c|c|c|}
\hline \multirow[t]{2}{*}{ Prof. } & \multicolumn{2}{|c|}{ pH } & \multirow[t]{2}{*}{$\mathrm{Ca}^{2+}$} & \multirow[t]{2}{*}{$\mathbf{M g}^{2+}$} & \multirow[t]{2}{*}{$\mathbf{K}^{+}$} & \multirow[t]{2}{*}{$\mathbf{H}^{+}+\mathbf{A l}^{3+}$} & \multirow[t]{2}{*}{$\mathbf{S}$} & \multirow[t]{2}{*}{ CтC } & \multirow[t]{2}{*}{$\mathbf{v}$} \\
\hline & $\mathrm{H}_{2} \mathrm{O}$ & $\mathrm{KCI}$ & & & & & & & \\
\hline $\mathrm{cm}$ & & & 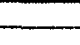 & 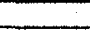 & $-\mathbf{m}$ & $00 \mathrm{~g}$ solo- & $\ldots$ & ב- & $\%$ \\
\hline \multicolumn{10}{|c|}{ Mata natural } \\
\hline $0-10$ & 4,54 & 3,92 & 0,17 & 0,11 & 0,06 & 21,1 & 0,34 & 21,44 & 1,58 \\
\hline $10-20$ & 4,30 & 3,95 & 0,05 & 0,07 & 0,03 & 18,3 & 0,15 & 18,45 & $\mathbf{0 , 8 1}$ \\
\hline $20-30$ & 4,50 & 4,06 & 0,02 & 0,08 & 0,01 & 14,2 & 0,11 & 14,31 & 0,76 \\
\hline $30-40$ & 4,81 & 4,17 & 0,01 & 0,09 & $\mathbf{0 , 0}$ & 10,3 & 0,10 & 10,40 & 0,96 \\
\hline $40-50$ & 4,92 & 4,21 & 0,03 & 0,09 & 0,0 & 8,9 & 0,12 & 9,02 & 1,33 \\
\hline \multicolumn{10}{|c|}{ Pastagem 4 anos } \\
\hline $0-10$ & 6,35 & 5,66 & 1,75 & 0,28 & 0,24 & 0,3 & 2,27 & 2,57 & $\mathbf{8 8 , 3 2}$ \\
\hline $10-20$ & 6,19 & 5,26 & 0,98 & 0,15 & 0,06 & 0,3 & 1,19 & 1,49 & 79,86 \\
\hline $20-30$ & 5,77 & 4,88 & 0,46 & 0,11 & 0,04 & 0,8 & 0,61 & 1,41 & 43,26 \\
\hline $30-40$ & 5,35 & 4,63 & 0,37 & 0,12 & 0,03 & 1,6 & 0,52 & 2,12 & 24,52 \\
\hline $40-50$ & 5,19 & 4,43 & 0,21 & 0,12 & 0,01 & 3,2 & 0,34 & 3,54 & 9,60 \\
\hline \multicolumn{10}{|c|}{ Pastagem 10 anos. } \\
\hline $0-10$ & 5,52 & 4,73 & 0,18 & 0,25 & 0,12 & 1,2 & 0,55 & 1,76 & 31,81 \\
\hline $10-20$ & 5,32 & 4,52 & 0,64 & 0,12 & 0,03 & 2,2 & 0,79 & 2,99 & 26,42 \\
\hline $20-30$ & 4,95 & 4,25 & 0,20 & 0,04 & $\mathbf{0 , 0}$ & 6,0 & 0,24 & 6,24 & 3,84 \\
\hline $30-40$ & 4,88 & 4,23 & 0,13 & 0,02 & 0,10 & 7,9 & 0,25 & 8,16 & 3,18 \\
\hline $40-50$ & 4,89 & 4,27 & 0,15 & 0,03 & 0,0 & 7,2 & 0,18 & 7,38 & 2,43 \\
\hline \multicolumn{10}{|c|}{ Pastagem 15 anos } \\
\hline $0-10$ & 6,0 & 5,10 & 1,02 & 0,25 & 0,61 & 0,6 & 1,88 & 2,48 & 75,80 \\
\hline $10-20$ & 5,97 & 4,95 & 0,70 & 0,12 & 0,35 & 0,6 & 1,17 & 1,78 & 66,29 \\
\hline $20-30$ & 5,92 & 4,94 & 0,47 & 0,10 & 0,17 & 0,7 & 0,74 & 1,44 & 51,38 \\
\hline $30-40$ & 5,85 & 5,05 & 0,38 & 0,08 & 0,12 & 0,7 & 0,58 & 1,28 & 45,31 \\
\hline $40-50$ & 5,45 & 4,87 & 0,34 & 0,07 & 0,04 & 1,0 & 0,45 & 1,46 & 31,50 \\
\hline
\end{tabular}




\subsubsection{Amostragem.}

Foram realizadas duas amostragens, a primeira ocorreu em Julho de 1991, onde foram colhidas as amostras para biomassa microbiana e os estoques de carbono e nitrogênio. A segunda amostragem deu-se em Abril de 1993 e coletaram-se amostras para as determinações das caracteríticas químicas e físicas do solo.

Durante a primeira amostragem foram colhidas, de cada área, três amostras aleatoriamente através de cilindros, com diâmetros de 16 $\mathrm{cm}$, à profundidades de $0-10 ; 10-20$ e 20-30 cm; sendo que, no segundo ponto a amostragem estendeu-se às camadas 30-40 e 40-50 cm de profundidade. $O$ volume colhido para cada amostra foi de $503 \mathrm{~cm}^{3}$ de solo.

As amostras colhidas no segundo período foram retiradas de três lados de uma trincheira $(1,0 \mathrm{mx} 1,0 \mathrm{mx} 1,0 \mathrm{~m})$, homogeneizadas e retirado $1,0 \mathrm{Kg}$ para as análises químicas.

\subsubsection{Preparação das Amostras.}

As amostras acondicionadas em sacos plásticos com respiros foram enviadas ao laboratório de Química do Solo do CENA (Piracicaba) por via aérea. No laboratório, foram peneiradas para a retirada das raízes. De cada amostra retirou-se uma subamostra de $100 \mathrm{~g}$ para a análise do carbono e nitrogênio total e do $\delta^{13} \mathrm{C}$. Estas subamostras foram secas ao ar, peneiradas a $2 \mathrm{~mm}$ e moidas a 100 meshes.

$\mathrm{O}$ restante das amostras foram corrigidas a $50 \%$ da capacidade de campo do solo, incubadas por uma semana e guardadas em 
câmara fria para a determinação da biomassa microbiana.

\subsection{Determinação da Densidade do solo.}

A densidade do solo foi determinada através do método do cilindro volumétrico de BLAKE \& HARTGE (1986), onde amostras de solo coletadas por cilindros foram secas à $105^{\circ} \mathrm{C}$ e a densidade calculada pela seguinte fórmula:

Densidade $\left(\mathrm{g} / \mathrm{cm}^{3}\right)=$ massa do solo $\left(105^{\circ} \mathrm{C}\right) /$ volume do cilindro

\subsection{Determinação do Estoque de Carbono Total.}

Foi realizada por combustão a seco, em amostras secas ao ar, peneiradas a $2 \mathrm{~mm}$ e moidas a 100 meshes, utilizando-se o equipamento Whostof-Carmograph 12A.

Considerando que a densidade dos solos variam entre 1.31 e $0.87 \mathrm{~g} / \mathrm{cm}^{3}$ os dados relativos ao estoque de carbono das pastagens foram corrigidos matematicamente, sendo que, a mata foi escolhida como referência. Em seguida foram calculadas as camadas hipotéticas,considerando uma densidade igual a $1,0 \mathrm{~g} / \mathrm{cm}^{3}$, correspondentes à cada camada. Os estoques nas pastagens foram calculados para estas camadas hipotéticas e assim puderam ser comparados as camadas da mata natural. $\mathrm{O}$ conteúdo total de carbono foi convertido em tha. 


\subsection{Determinação da Origem da Matéria Orgânica do Solo.}

A origem da matéria orgânica do solo foi determinada pela análise do ${ }^{13} \mathrm{C}$ obtida a partir da liberação do $\mathrm{CO}_{2}$ devido à combustão a $550^{\circ} \mathrm{C}$, em tubos pirex selados e presença de $\mathrm{CuO}$ e análise em espectrômetro de massa FINIGANN, de acordo com os procedimentos utilizados na Seção de Isótopos Estáveis do CENA (Centro de Energia Nuclear na Agricultura). A abundância natural de cada amostra foi expressa em $\delta^{13} \mathrm{C} \%$., usando como referência o padrão internacional PDB, de acordo com a seguinte equação:

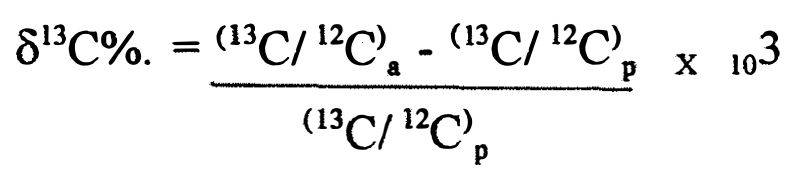

onde: $\mathrm{a}=$ amostra

$$
\mathrm{p}=\text { padrão }
$$

\subsubsection{Determinação do Carbono proveniente da pastagem e remanescente da floresta.}

Após a determinação do teor de carbono orgânico total (Cs) e abundância natural do ${ }^{13} \mathrm{C}$ e considerando que a matéria orgânica do solo é formada só por compostos derivados da floresta inicial ou da pastagem, consideram-se duas equacões (CERRI,1986): 


$$
\mathrm{Cs}=\mathrm{Cf}+\mathrm{Cp}
$$

$\mathrm{Cs} X \delta^{13} \mathrm{Cs}=\mathrm{Cf} X \delta^{13} \mathrm{Cf}+\mathrm{Cp} \times \delta^{13} \mathrm{Cp}$

De acordo com as equações obtem-se:

$$
\mathrm{Cp}(\%)=\frac{\delta-\delta 0}{\delta 1 \delta 0} \times 100 \text { e } \mathrm{Cf}(\%)=100-\mathrm{Cp}
$$

onde: $\delta=$ valores de $\delta^{13} \mathrm{C}$ das amostras sob pastagem.

$$
\delta 1=\text { média dos valores de } \delta^{13} \mathrm{C} \text { dos resíduos da }
$$

pastagem.

$$
\begin{aligned}
& \delta 0=\text { valores de } \delta^{13} \mathrm{C} \text { das amostras sob floresta. } \\
& \mathrm{Cp}=\text { teor de carbono derivado da pastagem. } \\
& \mathrm{Cf}=\text { teor de carbono derivado da floresta. }
\end{aligned}
$$

\subsubsection{Determinação do Carbono Estável e Biodegradável.}

As frações estáveis e biodegradáveis do carbono da floresta foram calculadas através das seguintes equações exponencias (CERRI,1986),

$$
\begin{aligned}
& C f=C f_{e}+C f_{b} X\left(\exp -K_{f}(t)\right) \\
& C p=C c X\left(1-\exp -K_{c}(t)\right)
\end{aligned}
$$

onde: $\mathrm{Cc}=$ quantidade máxima de $\mathrm{C}$ derivada da pastagem.

$\mathrm{K}_{\mathrm{f}}$ e $\mathrm{K}_{\mathrm{c}}=$ respectivas constantes de decaimento do $\mathrm{C}$ 
orgânico da floresta e pastagem.

$\mathrm{Cf}_{\mathrm{e}}$ e $\mathrm{Cf}_{\mathrm{b}}=$ frações estável e biodegradável derivada

da floresta.

\subsection{Determinação do Estoque de Nitrogênio Total.}

Amostras secas,peneiradas a $2 \mathrm{~mm}$ e moidas a 100 meshes foram digeridas e destiladas de acordo com o método micro-Kjendahl descrito por BREMNER E SHAW (1958). O conteúdo de nitrogênio em t/ha foi calculado através da densidade do solo e espessura da camada.

\subsection{Estimativa da Biomassa microbiana .}

\subsubsection{Estimativa da Biomassa Microbiana $C$ pelo Método da Fumigação-Incubação.}

A biomassa microbiana $\mathrm{C}$ foi medida pelo método Fumigação-Incubação de JENKINSON \& POWLSON (1976) (Figura 02) que consite em comparar o fluxo de $\mathrm{C}-\mathrm{CO}_{2}$ entre uma amostra esterilizada e posteriormente inoculada a outra não esterilizada. A esterilização foi realizada pela fumigação de amostras de terra (equivalente a $40 \mathrm{~g}$ de terra seca) em atmosfera de clorofómio purificado, por 24 horas em dessecador. Depois desse periodo, a amostra foi defumigado por repetidas aspirações com bomba de vácuo e inoculada com terra natural. $\mathrm{O}$ frasco com a amostra esterilizada foi introduzido, juntamente com um outro frasco contendo 10 $\mathrm{ml}$ de $\mathrm{NaOH} 1 \mathrm{~N}$ em jarros de vidro, permanecendo incubados por um período de 10 dias. Após este período, os jarros foram abertos e os frascos 
de soda foram trocados por outros que permaneceram por mais 10 dias em incubação. Imediatamente após a troca, a soda foi titulada com $\mathrm{HCl} 0,5 \mathrm{~N}$. A biomassa microbiana foi quantificada pela seguinte fórmula:

$$
\mathrm{B}=\mathrm{F} / \mathrm{K}_{\mathrm{ci}}
$$

onde:

$\mathrm{B}=$ biomassa microbiana expressa em ug $\mathrm{C}-\mathrm{CO}_{2} / \mathrm{g}$ solo.

$\mathrm{F}=$ diferença entre a quantidade de carbono evoluído da amostra incubada durante os primeiros 10 dias e da amostra incubada durante os 10 dias restantes.

$\mathrm{K}_{\mathrm{ci}}=$ coeficiente de mineralização $=0,45$

\subsubsection{Estimativa da Biomassa Microbiana $C$ pelo Método da Fumigação-Extração.}

O método de Incubação-Extração (VANCE et al.,1987) (Figura 03) também foi utilizado para a determinação da biomassa microbiana C. As amostras de terra, fumigadas e testemunhas, correspondendo a $25 \mathrm{~g}$ de terra seca, foram transferidas a erlenmeyer de 250 $\mathrm{ml}$, adicionando-se $100 \mathrm{ml}$ de $\mathrm{K}_{2} \mathrm{SO}_{4}$ 0,5M. O conjunto foi agitado por 1 hora e a suspensão resultante filtrada em papel de filtro. $O$ carbono orgânico foi determinado pela digestão de $8 \mathrm{ml}$ do extrato filtrado com $2 \mathrm{ml}$ de $\mathrm{K}_{2} \mathrm{Cr}_{2} \mathrm{O}_{7} 66,7 \mathrm{mM}, 10 \mathrm{ml}$ de $\mathrm{H}_{2} \mathrm{SO}_{4}$ conc. e $5 \mathrm{ml} \mathrm{de} \mathrm{H}_{3} \mathrm{PO}_{4}$ conc., durante 1 hora. $\mathrm{O}$ excesso de dicromato foi determinado por titulação com Sulfato Ferroso de Amônio 33,3 mM em $\mathrm{H}_{2} \mathrm{SO}_{4} 0,4 \mathrm{M}$, usando-se fenantrolina como 
indicador. O carbono extraível foi calculado assumindo que $1 \mathrm{ml} \mathrm{de} \mathrm{K}_{2} \mathrm{Cr}_{2} \mathrm{O}_{7}$ $66,7 \mathrm{mM}$ é equivalente a $1200 \mathrm{ugC}$.

Para a biomassa microbiana o cálculo foi feito pela seguinte relação:

$$
\text { Biomassa } \mathrm{C}=\mathrm{EC} / \mathrm{K}_{\mathrm{ce}}
$$

onde:

$\mathrm{EC}=$ diferença entre o carbono extraído dos tratamentos fumigado e testemunha, expressos em ug $\mathrm{C} / \mathrm{g}$ solo.

$\mathrm{K}_{\mathrm{ce}}=$ coeficiente de mineralização $=0,33$.

\subsubsection{Estimativa da Biomassa Microbiana $\mathbf{N}$ pelo Método da} Fumigação-Extração

A biomassa microbiana $\mathrm{N}$ foi quantificada pelo método da Fumigação-Extração de BROOKES et al. (1985), onde o $\mathrm{N}$ contido no extrato, extraído com $\mathrm{K}_{2} \mathrm{SO}_{4} 0,5 \mathrm{M}$, das amostras fumigadas e testemunhas é determinado através do método de digestão micro-Kjendahl.O coeficiente de mineralização $\left(\mathrm{K}_{\mathrm{n}}\right)$ usado no cálculo da biomassa $\mathrm{N}$ foi de 0,54 . 


\section{MÉTODO: JENKINSON \& POWLSON (1976).} FUMIGACĀO - INCUBAÇÃO.

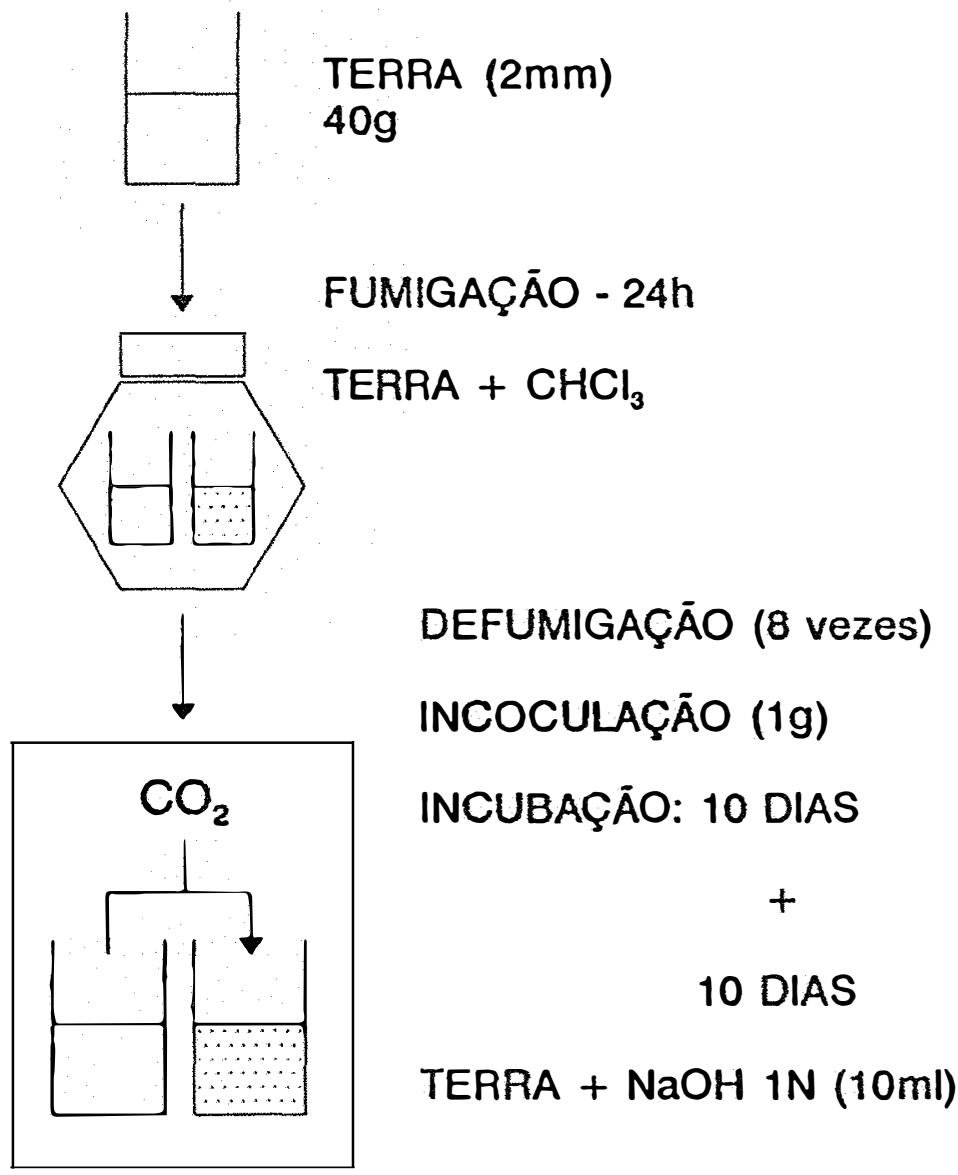

TITULAÇĀO: $10 \mathrm{ml} \mathrm{NaOH}+2 \mathrm{ml} \mathrm{BaCl} 2$ sat.

$\mathrm{HCl} 0,5 \mathrm{~N}+$ ortofenolftaleina

BIOMASSA $=\left(\mathrm{C}-\mathrm{CO}_{2} 10\right.$ DIAS $)-\left(\mathrm{C}-\mathrm{CO}_{2} 20\right.$ DIAS $) / \mathrm{K}_{\mathrm{CI}}$

Figura 02 - Esquema do método da Fumigação-Incubação de JENKINSON \& POWLSON (1976). 


\section{MÉTODO: VANCE et al (1987) \\ FUMIGACÃO - EXTRACÃO}

\section{AMOSTRA FUMIGADA \\ AMOSTRA CONTROLE}

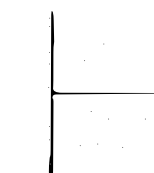

TERRA $(2 \mathrm{~mm})$

$25 \mathrm{~g}$
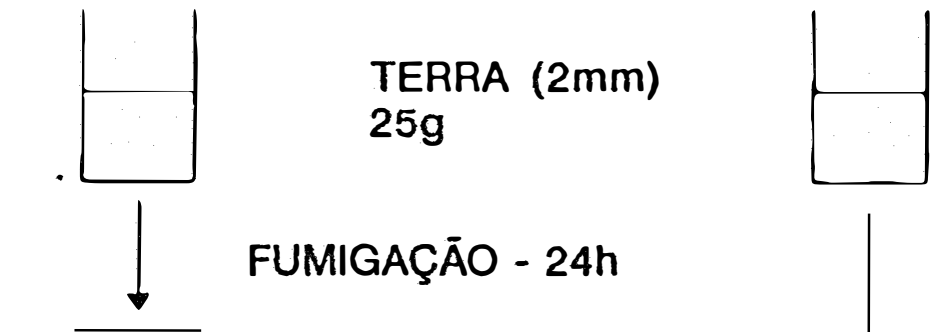

FUMIGAÇĀO - 24h

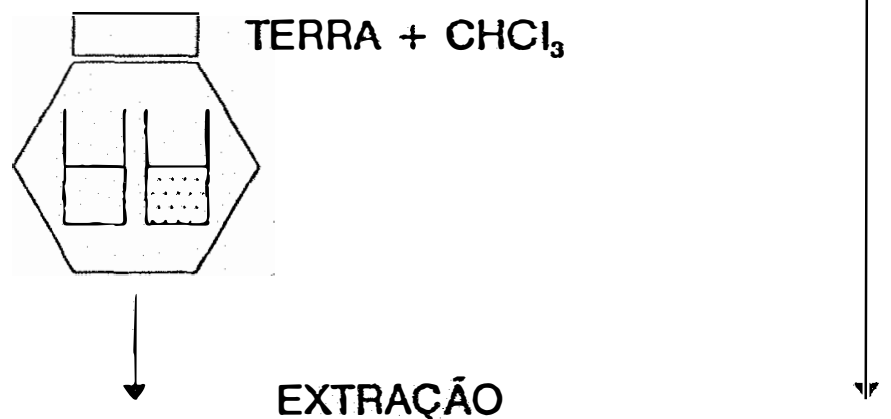

$\mathrm{SOLO}+100 \mathrm{ml} \mathrm{K}_{2} \mathrm{SO}_{4}(0,5 \mathrm{M})$ AGITAÇAOO $1 \mathrm{~h}$

FILTRAÇĀO

$$
\begin{aligned}
& \begin{array}{c}
\text { DIGESTĀO } \\
\text { ih }
\end{array} \quad\left\{\begin{array}{l}
8 \mathrm{ml} \mathrm{FITRADO} \\
2 \mathrm{ml} \mathrm{K} \mathrm{Cr}_{2} \mathrm{O}_{7} 66,7 \mathrm{mM} \\
10 \mathrm{ml} \mathrm{H} \mathrm{H}_{2} \mathrm{SO} \mathrm{O} c . \\
5 \mathrm{ml} \mathrm{H} \mathrm{PO}_{4} \text { conc. }
\end{array}\right. \\
& \text { TITULAÇĀO }\left\{\begin{array}{l}
\text { Sulfato ferroso de } \\
\text { amonio } 33,3 \mathrm{mM} \text { em } \\
\mathrm{H}_{2} \mathrm{SO}_{4} 0,4 \mathrm{M} \\
\text { fenantrolina }
\end{array}\right.
\end{aligned}
$$

BIOMASSA $=\left(\mathrm{C}_{\text {Extraido amostra fumigada }}\right)-\left(\mathrm{C}_{\text {Extraldo controle }}\right) / \mathrm{K}_{\mathrm{CE}}$

Figura 03 - Esquema do método da Fumigação-Extração de VANCE et al (1987). 


\section{RESULTADOS E DISCUSSĀO.}

\subsection{Distribuição do Carbono e Nitrogênio do Solo.}

A Tabela 02 contêm os dados referentes à densidade do solo e as porcentagens de carbono e nitrogênio presente nas camadas, bem como a relação $\mathrm{C} / \mathrm{N}$ das áreas de mata natural e pastagens.

Observou-se que nos primeiros $20 \mathrm{~cm}$ superficiais do solo, a densidade aumentou progressivamente com o tempo de cultivo, mostrando que a introdução da pastagem leva a uma compactação do solo. O aumento da densidade do solo com o tempo de cultivo foi demostrado por MARTINS (1987), CERRI et al. (1991) e NEIll et al. (1993). Vários estudos indicam que o tipo de método usado na implantação da pastagem é um importante fator que contribui para a compactação e que o uso de máquinas agrícolas leva a um maior aumento da densidade do solo. (CHAUVEL el al.,1991; BUSCHBACHER et al.,1988)

As pastagens com 15 e 4 anos apresentaram aumentos de no teor de carbono do solo em relação à mata natural nos primeiros $10 \mathrm{~cm}$. Contudo a pastagem com 10 anos sofreu uma diminuição; na camada de 10$20 \mathrm{~cm}$ de profundidade houve redução de aproximadamente $50 \%$ nas áreas 
de mata natural e pastagens de 4 e 10 anos, esta redução chegou a $40.0 \%$ na pastagem com 15 anos.

Tabela 02 - Distribuição da porcentagem de carbono, do nitrogênio e da densidade do solo.

\begin{tabular}{|c|c|c|c|c|}
\hline Profundidade & d & $\mathbf{C}$ & $\mathbf{N}$ & $\mathrm{C} / \mathrm{N}$ \\
\hline $\mathbf{c m}$ & $\mathbf{g} / \mathbf{c m}^{3}$ & -- & $-\cdots$ & \\
\hline \multicolumn{5}{|c|}{ Mata natural } \\
\hline $0-10$ & 0.87 & 2.53 & 0.21 & 12.04 \\
\hline $10-20$ & 0.99 & 1.27 & 0.10 & 12.70 \\
\hline 20-30 & 1.09 & 1.08 & 0.08 & 13.50 \\
\hline $30-40$ & 1.03 & 0.61 & 0.06 & 10.16 \\
\hline $40-50$ & 1.18 & 0.44 & 0.05 & 8.80 \\
\hline \multicolumn{5}{|c|}{ Pastagem 4 anos } \\
\hline $0-10$ & 1.04 & 2.72 & 0.28 & 9.71 \\
\hline $10-20$ & 1.16 & 1.39 & 0.11 & 12.63 \\
\hline 20-30 & 1.18 & 0.97 & 0.09 & 10.77 \\
\hline $30-40$ & 1.29 & 0.88 & 0.07 & 12.57 \\
\hline $40-50$ & 1.25 & 0.83 & 0.07 & 11.85 \\
\hline \multicolumn{5}{|c|}{ Pastagem 10 anos } \\
\hline $0-10$ & 1.09 & 2.36 & 0.18 & 13.11 \\
\hline $10-20$ & 1.25 & 1.19 & 0.10 & 11.90 \\
\hline 20-30 & 1.31 & 0.92 & 0.07 & 13.14 \\
\hline $30-40$ & 1.30 & 0.79 & 0.05 & 15.80 \\
\hline $40-50$ & 1.21 & 0.62 & 0.05 & 12.40 \\
\hline \multicolumn{5}{|c|}{ Pastagem 15 anos } \\
\hline $0-10$ & 1.20 & 2.96 & 0.22 & 13.45 \\
\hline $10-20$ & 1.28 & 1.20 & 0.11 & 10.90 \\
\hline 20-30 & 1.30 & 0.87 & 0.07 & 12.42 \\
\hline \multirow[t]{2}{*}{$30-40$} & & 0.75 & 0.07 & 10.71 \\
\hline & 1.24 & & & \\
\hline $40-50$ & 1.28 & 0.67 & 0.06 & 11.16 \\
\hline
\end{tabular}


O teor de carbono do solo tende a uma diminuição ao longo do perfil do solo, mas em algumas camadas, permaneceu estável.

Observou-se, também, que a área sob mata natural apresentou maior redução, a partir de $30 \mathrm{~cm}$ de profundidade, do que as áreas sob pastagens.

Com relação ao teor de nitrogênio, a área que apresentou o maior aumento foi a pastagem com 4 anos de implantação; a pastagem com 15 anos praticamente igualou-se à mata natural, enquanto que a pastagem com 10 anos apresentou redução de 14,3\%.

Do mesmo modo que o teor de carbono, o nitrogênio concentrou-se nos primeiros $10 \mathrm{~cm}$ do solo e diminuiu gradativamente a medida que a profundidade aumentou.

A relação $\mathrm{C} / \mathrm{N}$ apresentou um comportamento variável ao longo do perfil, sendo que, nos primeiros $10 \mathrm{~cm}$, a pastagem com 4 anos mostrou a menor relação $\mathrm{C} / \mathrm{N}$ e as pastagens com 10 e 15 anos aumentaram em relação ã mata natural. Estes valores são diferentes dos encontrados por CERRI (1989), onde a relação $\mathrm{C} / \mathrm{N}$ do latossolo original não foi significativamente modificada com a implantação da pastagem e dos de NEILL et al. (1993), onde a relação $\mathrm{C} / \mathrm{N}$ foi menor em todas as pastagens.

$\mathrm{Na}$ camada de $10-20 \mathrm{~cm}$ houve uma inversão na relação $\mathrm{C} / \mathrm{N}$, sendo que a pastagem com 4 anos igualou-se à mata natural e as pastagens com 10 e 15 anos diminuiram.

De um modo geral, a relação $\mathrm{C} / \mathrm{N}$ foi maior na área sob pastagem com 10 anos, variando de 11,9 a 15,8. Nas pastagens com 4 e 15 anos, a variação foi de 9,7 a 12,6 e 10,7 a 13,4; na área sob mata natural, esta variação foi de 8,8 a 12,0 . 


\subsection{Conteúdo do Carbono do Solo.}

O conteúdo de carbono do solo, em tha, das áreas estudadas encontran-se na Tabela 03 e Figura 04.

Verificou-se que o conteúdo de carbono da camada superficial do solo $(0-10 \mathrm{~cm})$ cultivado por 4 e 15 anos apresentaram aumentos de 1,6 tC/ha e 3,7 tC/ha em relação ao conteúdo de carbono do solo sob mata natural; estes aumentos correspondem a $7,3 \%$ e $16,9 \%$. 0 solo cultivado por 10 anos apresentou uma diminuição de 1,5 tC/ha que provavelmente deve-se ao fato de ter sido cultivado por dois anos consecutivos com milho antes da implantação da pastagem, pois o cultivo ocasionaria uma diminuição do carbono através da retirada da cultura do solo. Apesar da pastagem de 15 anos também ter sido cultivada com milho por um ano, a entrada do carbono pela pastagem e o tempo decorrido compensaram a perda inicial ocasionada pelo cultivo do milho.

Nos vinte centímetros superficiais do solo estão estocados 34,$5 ; 37,8 ; 34,8$ e 43,4 tC/ha, nas áreas de mata natural e pastagens de 4 , 10 e 15 anos respectivamente; correspondendo a 59,$7 ; 55,0 ; 54,2$ e $59,9 \%$ do carbono total até 50 centímetros de profundidade. Constata-se que os valores encontrados são inferiores ao de CERRI (1989) e ao encontrado por CHONE et al. (1991) em áreas da Amazônia Central.

Esses valores indicam que houve um acréscimo de 3,3 tC/ha e 8,9 tC/ha nas áreas de pastagens cultivadas por 4 e 15 anos, que encontra-se coerente com aquele encontrado por CERRI (1989) para uma pastagem com 8 anos que representa um valor intermediário e confirma que a implantação da pastagem leva, ao longo do tempo, a um aumento no 
conteúdo de carbono do solo; a quantidade de carbono presente na pastagem de 10 anos praticamente igualou-se à da mata natural.

Tabela 03 - Conteúdo de carbono do solo (t/ha) das áreas de pastagens e mata natural.

\begin{tabular}{|c|c|c|c|}
\hline \multirow[b]{2}{*}{ Area } & \multirow[b]{2}{*}{ Profundidade } & \multicolumn{2}{|c|}{ Carbono } \\
\hline & & da camada & acumulado \\
\hline & $\mathbf{c m}$ & $\ldots . . .$. & $\ldots . . .$. \\
\hline \multirow[t]{5}{*}{ Mata natural } & $0-10$ & 21,9 & 21,9 \\
\hline & $10-20$ & 12,6 & 34,5 \\
\hline & $20-30$ & 11,7 & 46,2 \\
\hline & $30-40$ & 6,3 & 52,5 \\
\hline & $40-50$ & 5,2 & 57,7 \\
\hline \multirow{5}{*}{$\begin{array}{l}\text { Pastagem } 4 \\
\text { anos }\end{array}$} & $0-10$ & 23,5 & 23,5 \\
\hline & $10-20$ & 14,3 & 37,8 \\
\hline & $20-30$ & 11,2 & 49,1 \\
\hline & $30-40$ & 9,5 & 58,5 \\
\hline & $40-50$ & 10,2 & 68,7 \\
\hline \multirow{5}{*}{$\begin{array}{l}\text { Pastagem } 10 \\
\text { anos }\end{array}$} & $0-10$ & 20,4 & 20,4 \\
\hline & $10-20$ & 14,4 & 34,8 \\
\hline & $20-30$ & 11,4 & 46,1 \\
\hline & $30-40$ & 9,1 & 55,3 \\
\hline & $40-50$ & 9,0 & 64,2 \\
\hline \multirow{5}{*}{$\begin{array}{l}\text { Pastagem } 15 \\
\text { anos }\end{array}$} & $0-10$ & 25,6 & 25,6 \\
\hline & $10-20$ & 17,8 & 43,4 \\
\hline & 20-30 & 11,6 & 54,9 \\
\hline & $30-40$ & 8,7 & 63,6 \\
\hline & $40-50$ & 8,7 & 72,4 \\
\hline
\end{tabular}



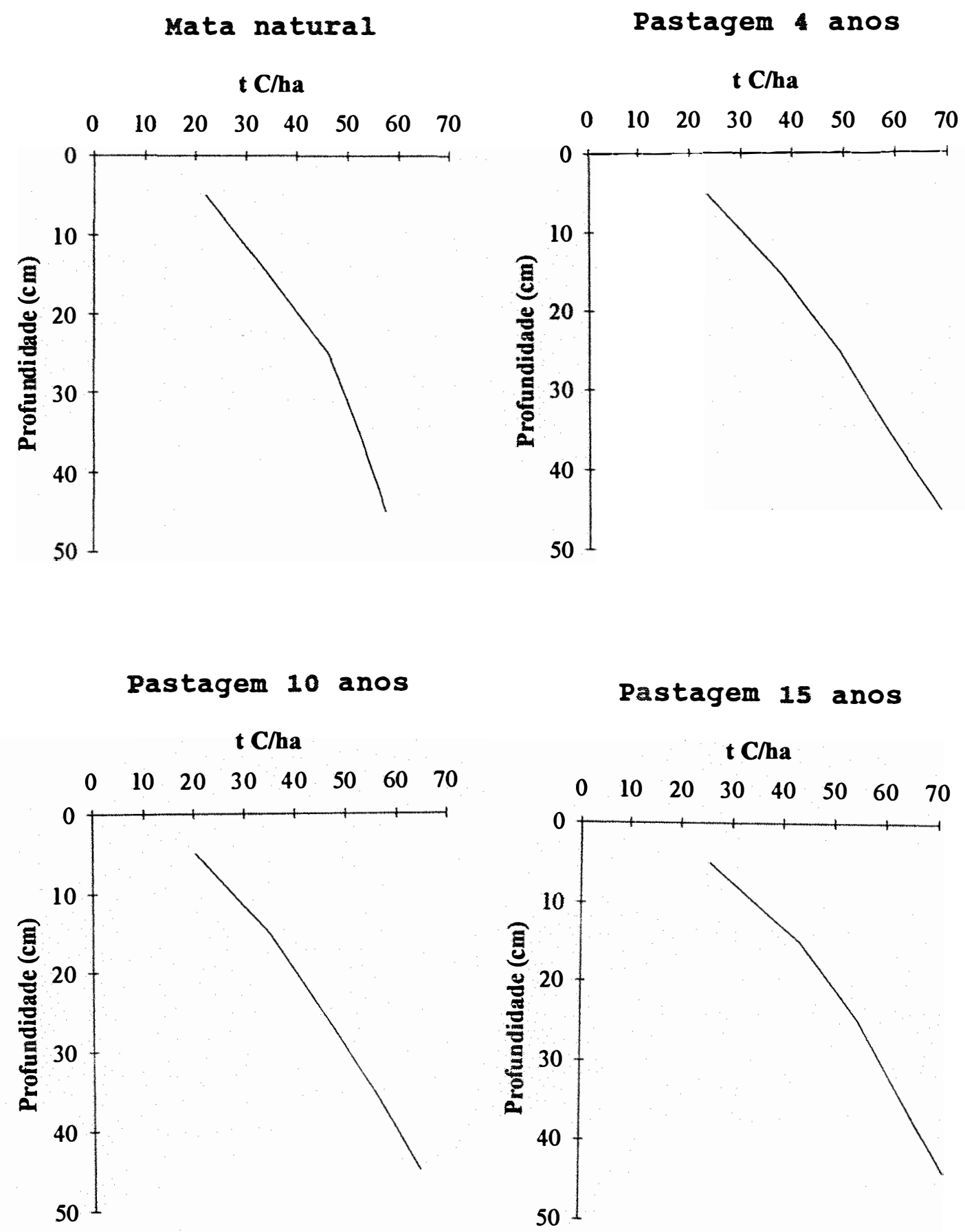

Figura 04 - Carbono total acumulado no solo das áreas com pastagem e mata natural. 
MORAES (1991), entretanto, verificou uma redução no conteúdo de carbono em pastagens com 3 e 8 anos, que seria ocasionada pela rápida mineralização do húmus biodegradável e à lenta incorporação de carbono derivado da pastagem, após o desmatamento. Esta redução foi demostrada por CERRI (1989) para uma pastagem com 2 anos, onde o conteúdo inicial diminuiu em $23,5 \%$

Constatou-se que estão estocados 44,$9 ; 45,7$ e 40,0\% do conteúdo de carbono total nas profundidades entre 30 e $50 \mathrm{~cm}$ nas áreas de pastagem cultivadas por 4, 10 e 15 anos, correspondendo a 30,9; 29,4 e 29,0 $\mathrm{tC} / \mathrm{h}$. Em relação ao solo sob mata natural, houve aumentos de 7,$7 ; 6,2$ e 5,8 tC/ha no conteúdo total do carbono do solo nas pastagens com 4, 10 e 15 anos de implantação.

O conteúdo de carbono, da camada $0-50 \mathrm{~cm}$ de profundidade, apresentou aumento de $8,2 \mathrm{tC} /$ ha e $3,7 \mathrm{tC} /$ ha entre a pastagem com 15 anos e as pastagens com 10 e 4 anos, respectivamente; e de 4,5 tC/ha entre a pastagem com 4 e a de 10 anos de implantação.

A maioria dos trabalhos existentes sobre as mudanças no estoque de carbono devido ao corte das florestas são derivados de áreas com culturas anuais e estas áreas mostram um padrão de mudança diferente. CERRI \& ANDEUX (1990), em solos com cana-de-açúcar, mostraram declínios no carbono total de $37,9 \%$ após 12 anos e 46,4\% após 50 anos de cultivo. 


\subsection{Constituição Isotópica da Matéria Orgânica dos Solos sob Mata Natural e Pastagens.}

A Figura 05 representa a distribuição dos valores da constituição isotópica de acordo com a profundidade nas áreas cultivadas com pastagens de 4,10 e 15 anos de implantação e na área de mata natural.

A medida que as pastagens tornam-se mais velhas, o $\delta^{13} \mathrm{C}$ do solo aumenta progessivamente, uma vez que há uma diluição isotópica através da entrada de material vegetal proveniente da pastagem, e esta variação é maior na camada superficial do solo. Este aumento progressivo foi demons rado também através dos estudos de CERRI (1989) em solos da Amazônia brasileira.

$\mathrm{Na}$ área sob mata natural, o $\delta^{13} \mathrm{C}$ foi de aproximadamente $-28 \%$ na camada superior, concordando com os resultados obtidos por CERRI (1989) e MORAES (1991). Em profundidade, houve um aumento para $-25,7 \%$.

Os valores observados nas áreas cutivadas, a $10 \mathrm{~cm}$ de profundidade, foram de $-25,8 \% ;-23,9 \%$ e $-22,4 \%$ para as pastagens com 4,10 e 15 anos, o que está de acordo com os resultados de MORAES (1991).

Com o aumento da profundidade, a diluição isotópica ocasionada pela entrada dos restos vegetais da pastagem torna-se menor e o $\delta^{13} \mathrm{C}$ das pastagens tornam-se praticamente iguais ao da mata, com uma variação de apenas $-0,8 \%$. Estes resultados estão de acordo com o encontrado por NEILL et al. (1993), que apresentaram diferenças de apenas 
$2,4 \%$ a uma profundidade de $30 \mathrm{~cm}$.

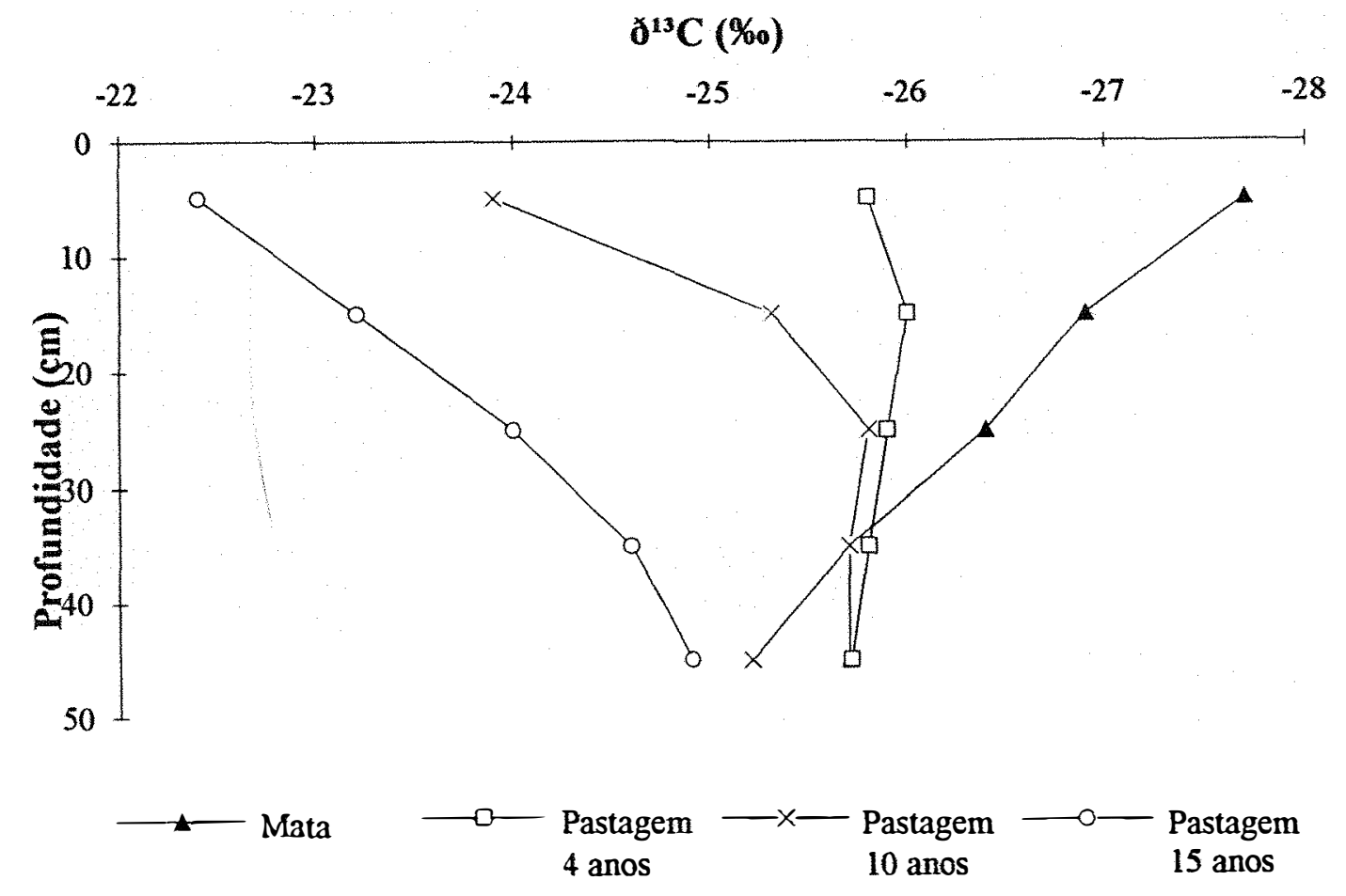

Figura 05 - Distribuição dos valores de $\delta^{13} \mathrm{C}$ das áreas com pastagens e mata natural.

\subsection{Modificações na Qualidade da Matéria Orgânica do Solo Devido à Implantação de Pastagens.}

A Tabela 04 e Figura 06 apresentam as duas origens da matéria orgânica do solo: o carbono remanescente da floresta, denominado $\mathrm{Cf}$, e o carbono introduzido ao solo pela pastagem, $\mathrm{Cp}$. 
Tabela 04 - Origem do carbono do solo das áreas sob pastagens com 4,10 e 15 anos de implantação. Carbono da floresta (Cf), Carbono da pastagem $(C p)$.

\begin{tabular}{|c|c|c|c|c|c|}
\hline \multirow{2}{*}{$\begin{array}{c}\text { Profundidade } \\
\mathbf{c m} \\
\end{array}$} & \multirow{2}{*}{$\begin{array}{c}\text { C total } \\
\text { t/ha }\end{array}$} & \multicolumn{2}{|c|}{ Cf } & \multicolumn{2}{|c|}{ Cp } \\
\hline & & $\mathbf{t} / \mathbf{h a}$ & $\%$ & t/ha & $\%$ \\
\hline \multicolumn{6}{|c|}{ Pastagem 4 anos } \\
\hline $0-10$ & 23,5 & 20,3 & 86,1 & 3,3 & 13,9 \\
\hline $0-20$ & 37,8 & 33,5 & 88,6 & 7,3 & 11,4 \\
\hline 0-30 & 49,1 & 44,3 & 90,4 & 4,7 & 9,6 \\
\hline $0-40$ & 58,5 & 53,9 & 92,0 & 4,7 & 8,0 \\
\hline $0-50$ & 68,7 & 64,1 & 93,3 & 4,6 & 6,7 \\
\hline \multicolumn{6}{|c|}{ Pastagem 10 anos } \\
\hline $0-10$ & 20,4 & 14,8 & 72,3 & 5,7 & 27,7 \\
\hline $0-20$ & 34,8 & 27,3 & 78,6 & 7,4 & 21,4 \\
\hline 0-30 & 46,1 & 38,1 & 82,7 & 8,0 & 17,3 \\
\hline $0-40$ & 55,3 & 47,3 & 85,5 & 8,0 & 14,5 \\
\hline $0-50$ & 64,2 & 55,9 & 87,0 & 8,4 & 13,0 \\
\hline \multicolumn{6}{|c|}{ Pastagem 15 anos } \\
\hline $0-10$ & 25,6 & 15,7 & 61,3 & 9,9 & 38,7 \\
\hline $0-20$ & 43,4 & 28,4 & 65,4 & 15,0 & 34,6 \\
\hline $0-30$ & 54,9 & 37,7 & 68,6 & 17,2 & 31,4 \\
\hline $0-40$ & 63,6 & 45,6 & 71,6 & 18,1 & 28,4 \\
\hline $0-50$ & 72,4 & 53,7 & 74,2 & 18,6 & 25,8 \\
\hline
\end{tabular}

Nos primeiros $20 \mathrm{~cm}$ superficiais do solo, o Cf das áreas de pastagens com 4, 10 e 15 anos forão de 33,$5 ; 27,3$ e $28,4 \mathrm{tC} /$ ha, representando cerca de 88,$6 ; 78,6$ e $65,5 \%$ do carbono total do solo, sendo semelhantes àqueles encontrados por BONDE et al. (1992) sobre um oxissol perto de Manaus, onde o carbono derivado da floresta era $83 \%$ do carbono total da camada superficial do solo numa pastagem com 3 anos e $80 \%$ numa pastagem com 8 anos; o carbono da pastagem correspondeu a 11,$4 ; 21,4 \mathrm{e}$ 
$34,6 \%$ do carbono total, indicando que houve uma diminuição de 2,89 ; 20,86 e $17,68 \%$ do conteúdo de carbono da floresta após 4,10 e 15 anos de implantação das pastagens e são inferiores aos encontados por CERRI (1989) que observou uma diminuição de $38 \%$ e $42,5 \%$ para pastagens com 2 e 8 anos.

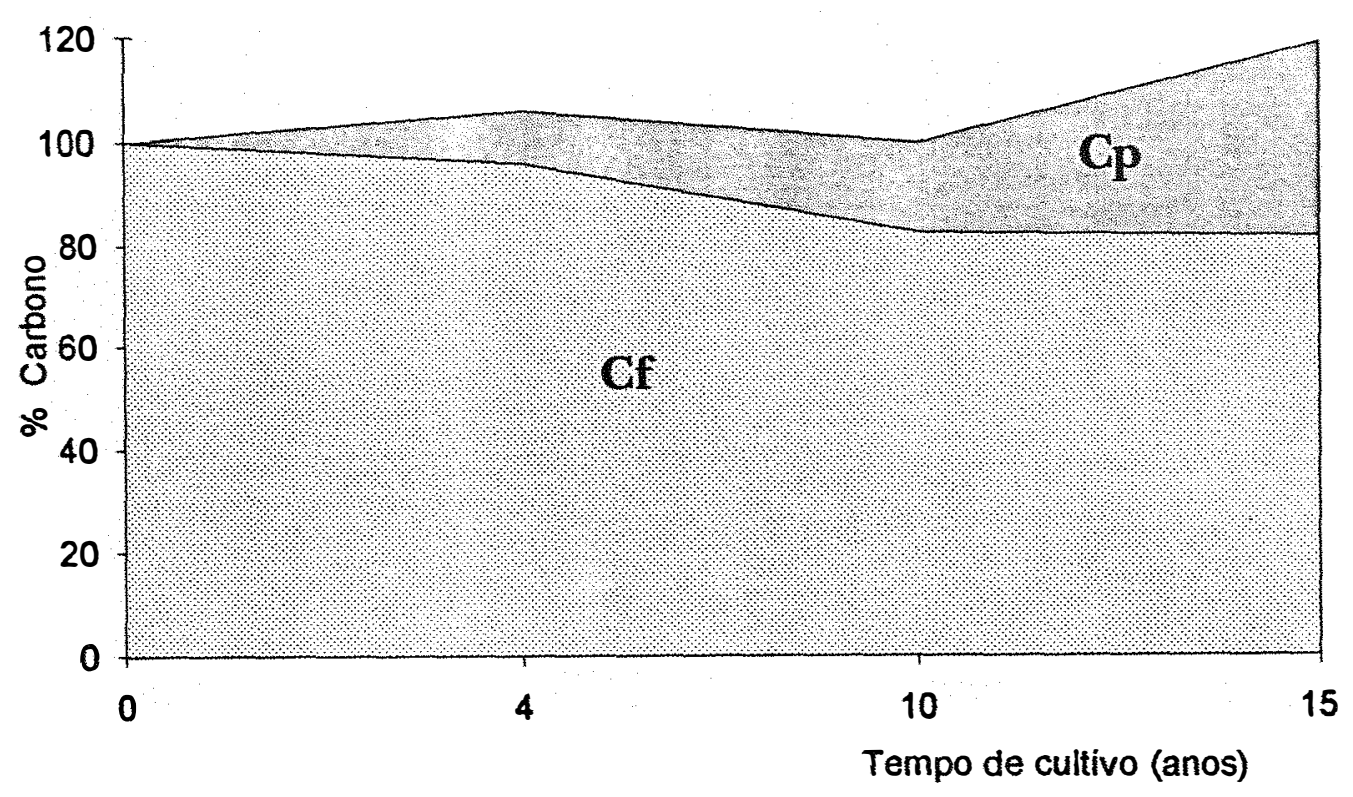

Figura 06 - Porcentagem de variação do carbono total, carbono da floresta e carbono da pastagem em função do tempo de cultivo a $30 \mathrm{~cm}$ de profundidade. Cf = carbono da floresta; $\mathbf{C}$ = carbono da pastagem.

Com o desmatamento, há uma diminuição progressiva do carbono derivado da floresta, uma vez que não há mais a entrada de plantas de ciclo fotossintético $\mathrm{C}_{3}$.

Com a introdução das pastagens, o carbono introduzido pela mesma aumenta com o tempo de cultivo e, a medida que aumenta-se a profundidade do solo o carbono remanescente da floesta aumenta, 
enquanto que o carbono proveniente da pastagem diminui.

\subsubsection{Carbono Estável e Biodegradável Derivado da Floresta.}

A Tabela 05 e Figura 07 apresentam os resultados do carbono da floresta estável (Cfe) e o carbono da floresta que é biodegradável ( $\mathrm{Cfb}$ ), bem como a quantidade total de carbono originário da floresta nas pastagens com 10 e 15 anos.

A fração estável e biodegradável da pastagem com 4 anos não foi possível de calcular devido a pequena diferença existente entre o estoque de carbono da mata natural, o que explica também a impossibilidade de calculo a 50 centímetro de profundidade nas pastagens de 10 e 15 anos.

Tabela 05 - Quantidade de carbono total da floresta (Cf), carbono da floresta estável (Cfe) e carbono da floresta biodegradável ( $\mathrm{Cfb}$ ).

\begin{tabular}{cccc}
\hline \multirow{2}{*}{ Profundidade } & Cf & Cfe & Cf f \\
\cline { 2 - 4 } cm & \multicolumn{3}{c}{ Carbono da floresta } \\
& Mata matural & \\
$0-30$ & 46,20 & 37,56 & \\
$0-40$ & 52,50 & 40,27 & 12,22 \\
& & & \\
$0-30$ & Pastagem 10 anos & 37,56 & 0,54 \\
$0-40$ & 38,10 & 40,27 & 7,03 \\
& 47,30 & & \\
& & & 0,14 \\
$0-30$ & Pastagem 15 anos & 37,56 & 5,33 \\
\hline
\end{tabular}

Nos primeiros vinte centímetros das pastagens com 10 e 
15 anos a fração estável e biodegradável não foi determinada, pois o carbono da floresta na pastagen com 15 anos de implantação mostrou-se maior devido à retirada do carbono do solo através do cultivo do milho na pastagem com 10 anos de implantação.

De acordo com os dados, o carbono da floresta estável é de 37,56 e 40,27 tC/ha nas profundidades de 30 e 40 centímetros, correspondendo a 81,29 e $76,70 \%$ do carbono total nativo.

Do total de carbono existente no solo após 10 e 15 anos de pastagens, nas profundidades $0-30$ e $0-40 \mathrm{~cm}, 81,47 \% ; 72,82 \%$ e $68,41 \%$; $63,31 \%$ correspondem ao carbono estável, significando que após 10 e 15 anos de implantação da pastagem, $1,17 \% ; 12,71 \%$ e $0,25 \% ; 8,38 \%$ do carbono estão sob a forma biodegradável e, deste modo, o carbono introduzido pela pastagem seria o maior responsável pelos processos biológicos do solo.

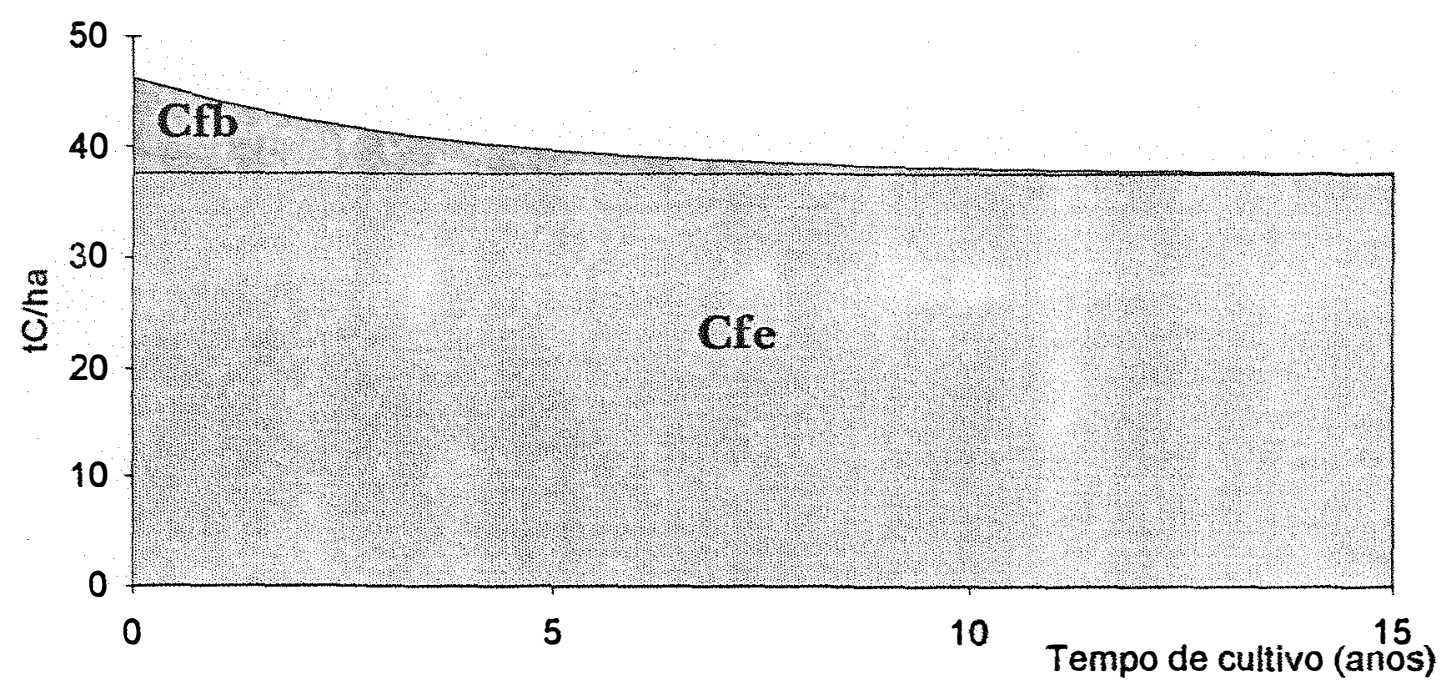

Figura 07 - Quantidade do carbono total da floresta (Cft), carbono da floresta estável (Cfe) e carbono da foresta biodegradável (Cfb) em função do tempo de cultivo a $30 \mathrm{~cm}$ de profundidade. 
Estes resultados mostram também que, como a quantidade de carbono da floresta aumenta com a profundidade, as frações biodegradável e estável acompanham este aumento e, à medida que o tempo de cultivo aumenta, a fração biodegradável diminui.

A Figura 08 esquematiza a quantidade de carbono total e sua origem nas áreas de mata natural e pastagens com 10 e 15 anos de implantação na profundidade de $30 \mathrm{~cm}$.

\subsection{Conteúdo do Nitrogênio do Solo}

Através da Tabela 06 e Figura 09, verificou-se que o estoque de nitrogênio do solo na camada $0-10 \mathrm{~cm}$ aumentou em $10,5 \%$ e 5,26\% após 4 e 15 anos da implantação da pastagem. A diminuição do conteúdo de nitrogênio em $15,8 \%$ em relação à mata, na pastagem com 10 anos foi provavelmente ocasionada devido ao cultivo da área com o milho. Considerando a camada $0-20 \mathrm{~cm}$, esta diminuição decresce para $6,67 \%$, uma vez que é na camada superficial do solo que e concentra-se a maior quantidade do nitrogênio estocado. CHONE et al. (1991) encontraram que o estoque de nitrogênio do solo até $20 \mathrm{~cm}$ de profundidade seguiu o mesmo padrão do estoque de carbono, com um pequeno decréscimo na pastagem com 2 anos e um aumento após 8 anos de implantação. Contudo, BUSCHBACHER et al. (1988) não encontraram relações claras entre o estoque de nitrogênio do solo e a idade da pastagem, mas o estoque de nitrogênio foi menor em áreas sob pastagens de 8 anos intensamente utilizadas comparado com pastagens de 8 anos pouco utilizadas. 


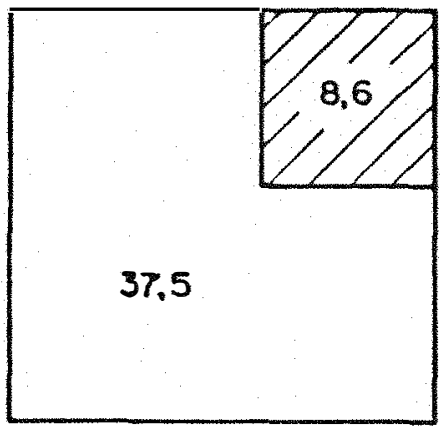

MATA NATURAL

$46,20+\mathrm{C} / \mathrm{ho}$

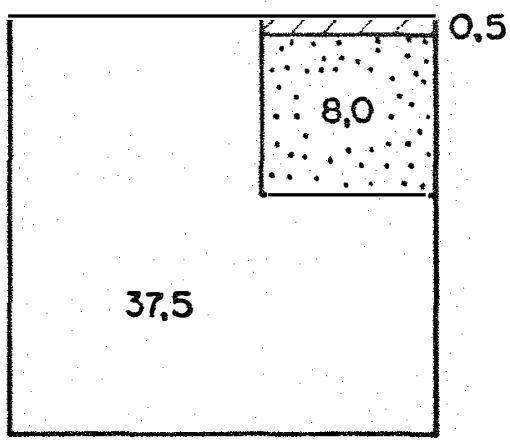

PASTAGEM 10 ANOS

$46,10+\mathrm{C} / \mathrm{ha}$

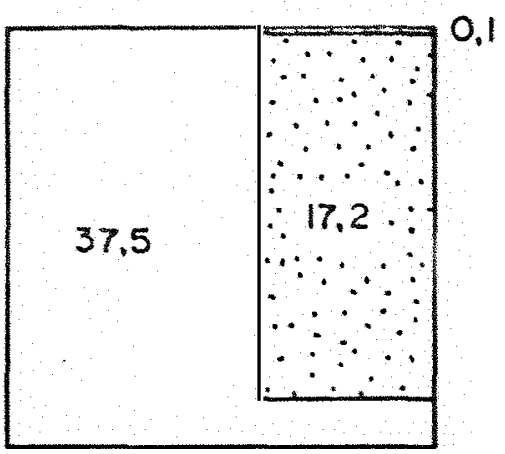

PASTAGEM 15 ANOS

$54,9+\mathrm{C} / \mathrm{ha}$

CARBONO DA FLORESTA ESTÁVEL CARBONO DA FLORESTA BIODEGRADÁVEL

$\because$ CARBONO DA PASTAGEM

Figura 08 - Esquema das quantidades de carbono da floresta estável, biodegradável e do carbono proveniente da pastagem na camada de $30 \mathrm{~cm}$. 
O aumento do nitrogênio do solo nas áreas sob pastagens deve-se, provavelmente, à fixação biológica do nitrogênio, uma vez que não houve entrada de nitrogênio através de adubações. Estes dados estão de acordo com o trabalho de PICOLLO et al. (1993), que observaram uma diminuição do valor de $\delta^{15} \mathrm{~N}$ em pastagens e concluiram que isto se deve a entrada de $\mathrm{N}$ derivado da fixação por bactérias de vida livre associadas com as gramíneas.

Tabela 06 - Conteúdo de Nitrogênio do solo (t/ha) das áreas de pastagens e mata natural.

\begin{tabular}{|c|c|c|c|}
\hline \multirow[b]{2}{*}{ Area } & \multirow[b]{2}{*}{ Profundidade } & \multicolumn{2}{|c|}{ Nitrogênio } \\
\hline & & da camada & acumulado \\
\hline & $\mathbf{c m}$ & & \\
\hline \multirow{5}{*}{ Mata natural } & $0-10$ & 1,9 & 1,9 \\
\hline & $10-20$ & 1,1 & 3,0 \\
\hline & $20-30$ & 0,9 & 3,9 \\
\hline & $30-40$ & 0,7 & 4,6 \\
\hline & $40-50$ & 0,6 & 5,2 \\
\hline \multirow[t]{5}{*}{ Pastagem 4 anos } & $0-10$ & 2,1 & 2,1 \\
\hline & $10-20$ & 1,3 & 3,4 \\
\hline & $20-30$ & 1,1 & 4,5 \\
\hline & $30-40$ & 0,9 & 5,4 \\
\hline & $40-50$ & 0,9 & 6,3 \\
\hline \multirow[t]{5}{*}{ Pastagem 10 anos } & $0-10$ & 1,6 & 1,6 \\
\hline & $10-20$ & 1,2 & 2,8 \\
\hline & $20-30$ & 0,9 & 3,7 \\
\hline & $30-40$ & 0,7 & 4,4 \\
\hline & $40-50$ & 0,7 & 5,1 \\
\hline \multirow[t]{5}{*}{ Pastagem 15 anos } & $0-10$ & 2,0 & 2,0 \\
\hline & $10-20$ & 1,5 & 3,5 \\
\hline & $20-30$ & 1,1 & 4,6 \\
\hline & $30-40$ & 0,8 & 5,4 \\
\hline & $40-50$ & 0,8 & 6,2 \\
\hline
\end{tabular}



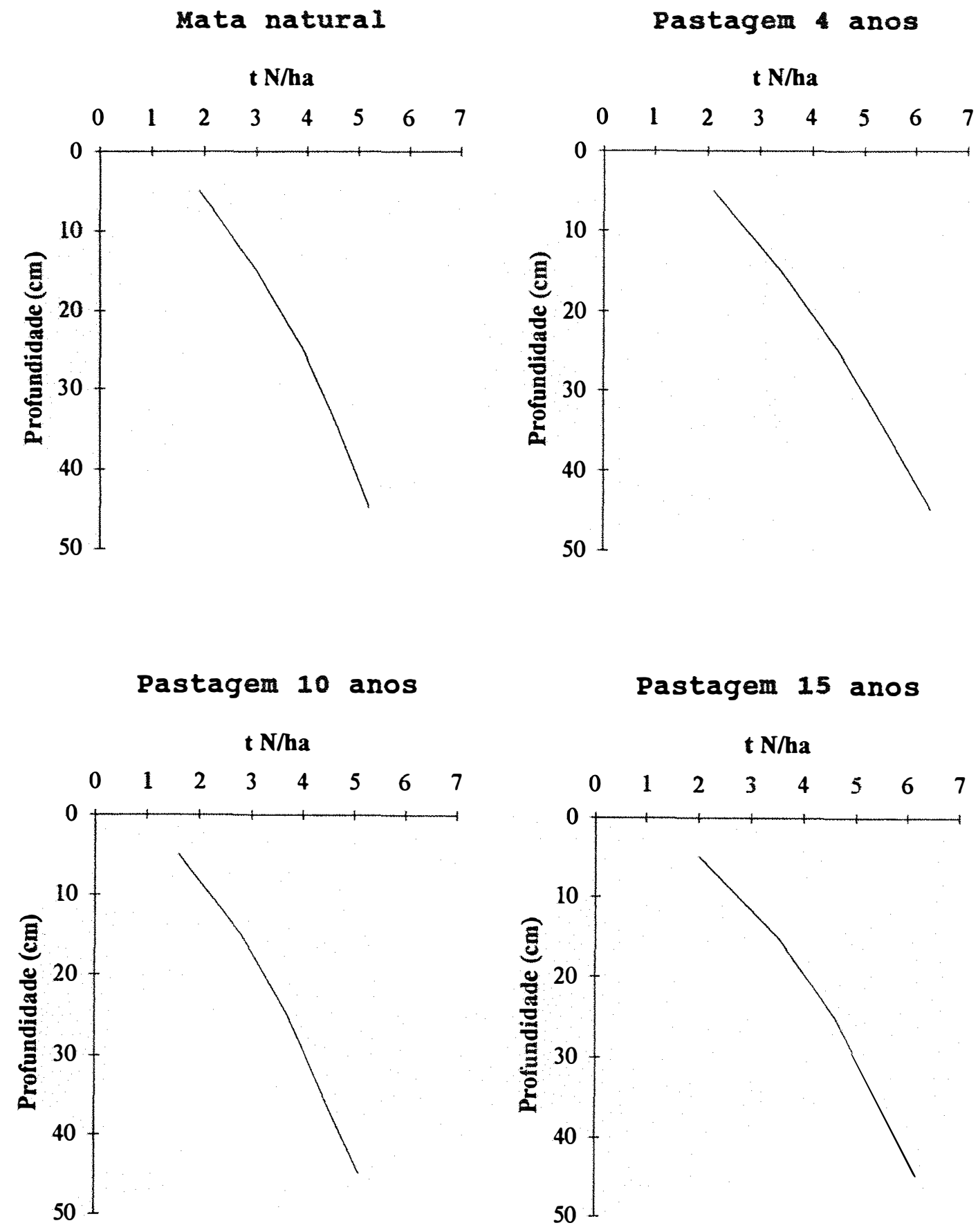

Figura 09 - Nitrogênio total acumulado no solo das áreas com pastagem e mata natural. 
Em relação ao conteúdo total de nitrogênio no solo até $50 \mathrm{~cm}$ de profundidade, a mata natural apresentou cerca de $36,5 \%$ do seu nitrogênio na camada $0-10 \mathrm{~cm}$, seguida da pastagem de 4 anos com $33,3 \%$ e das pastagens de 15 e 10 anos com $31,3 \%$ e $32,25 \%$.

Do mesmo modo que ocorreu com o estoque de carbono, à medida que a profundidade do solo aumenta há uma diminuição no estoque de nitrogênio do solo.

\subsection{A Estimativa da Biomassa Microbiana C Pelos Métodos Fumigação-Incubação e Fumigação-Extração.}

A biomassa microbiana estimada pelo méstodo FI variou de 673,52 a $299,44 \mu \mathrm{g} \mathrm{C} / \mathrm{g}$ terra nos primeiros $10 \mathrm{~cm}$ de profundidade; enquanto que, pelo método da FE, esta variação foi de 754,36 a 203,45 $\mu \mathrm{g}$ C/g terra ,como pode ser observado nas Tabelas 07 e 08 e Figuras 10 e 11 . De um modo geral, a estimativa obtida pelo métoda da FE mostrou-se maior do que a obtida pelo método FI. Contudo, o desvio padrão das amostras mostrou-se muito grande, devido à grande heterogeneidade na distribuição da biomassa microbiana no solo.

A relação entre os dois métodos foi realizada através da regressão linear do carbono da biomassa microbiana pelo método da FI em relação ao carbono extraído pelo método FE (Figura 12). 
Tabela 07 - Biomassa microbiana C determinada pelo método da FumigaçãoIncubação. Média de três repetições espaciais.

\begin{tabular}{|c|c|c|c|c|}
\hline \multirow{2}{*}{ Prof } & \multicolumn{2}{|c|}{$\mathrm{CO}_{2}$ liberado } & \multirow{2}{*}{$\mathbf{C i}^{1}$} & \multirow{2}{*}{ Biomassa } \\
\hline & Fumigado & testemunha & & \\
\hline $\mathbf{c m}$ & \multicolumn{4}{|c|}{ 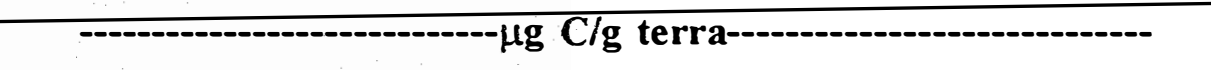 } \\
\hline \multicolumn{5}{|c|}{ Mata natural } \\
\hline $0-10$ & $251,45(27,8)$ & $110,0(37,0)$ & $141,42(57,5)$ & $314,26(127,9)$ \\
\hline $10-20$ & $76,0(37,1)$ & $46,25(19,4)$ & $29,75(17,6)$ & $66,11(39,2)$ \\
\hline $20-30$ & $77,25(42,7)$ & $39,58(21,7)$ & $37,67(28,1)$ & $83,70(62,5)$ \\
\hline $30-40^{2}$ & nd & nd & nd & nd \\
\hline $40-50^{2}$ & 64,75 & 47,50 & 17,25 & 38,33 \\
\hline \multicolumn{5}{|c|}{ Pastagem 4 anos } \\
\hline $0-10$ & $488,08(263,9)$ & $185,0(106,1)$ & $303,08(159,3)$ & $673,52(354,0)$ \\
\hline $10-20$ & $136,42(20,2)$ & $55,0(5,0)$ & $81,42(16,0)$ & $180,93(35,7)$ \\
\hline $20-30$ & $44,75(20,0)$ & $38,75(15,1)$ & $6,0(5,4)$ & $13,33(12,1)$ \\
\hline $30-40^{2}$ & nd & nd & nd & nd \\
\hline $40-50^{2}$ & nd & nd & nd & nd \\
\hline \multicolumn{5}{|c|}{ Pastagem 10 anos } \\
\hline $0-10$ & $258,92(29,1)$ & $124,17(17,5)$ & $134,75(27,0)$ & $299,44(60,0)$ \\
\hline $10-20$ & $124,75(45,8)$ & $58,28(22,7)$ & $66,47(51,4)$ & $147,72(114,3)$ \\
\hline $20-30$ & $54,75(8,6)$ & $17,50(5,0)$ & $37,25(5,0)$ & $82,78(11,1)$ \\
\hline $30-40^{2}$ & 44,75 & 30,0 & 14,75 & 32,78 \\
\hline $40-50^{2}$ & nd & nd & nd & nd \\
\hline \multicolumn{5}{|c|}{ Pastagem 15 anos } \\
\hline $0-10$ & $316,83(3,9)$ & $86,66(17,9)$ & $230,17(20,7)$ & $511,48(46,0)$ \\
\hline $10-20$ & $93,75(49,7)$ & $25,97(10,3)$ & $67,78(39,4)$ & $150,62(87,5)$ \\
\hline 20-30 & $44,18(21,8)$ & $13,15(7,8)$ & $31,03(29,5)$ & $68,95(65,7)$ \\
\hline $30-40^{2}$ & nd & nd & nd & nd \\
\hline $40-50^{2}$ & nd & nd & nd & nd \\
\hline
\end{tabular}

' $\mathrm{C}-\mathrm{CO}_{2}$ ilberado da amostra fumigada menos $\mathrm{C}-\mathrm{CO}_{2}$ liberado da amostra testemunha.

2 somnete uma repetição. nd $=$ não determinado; $($ ) desvio padrão. 

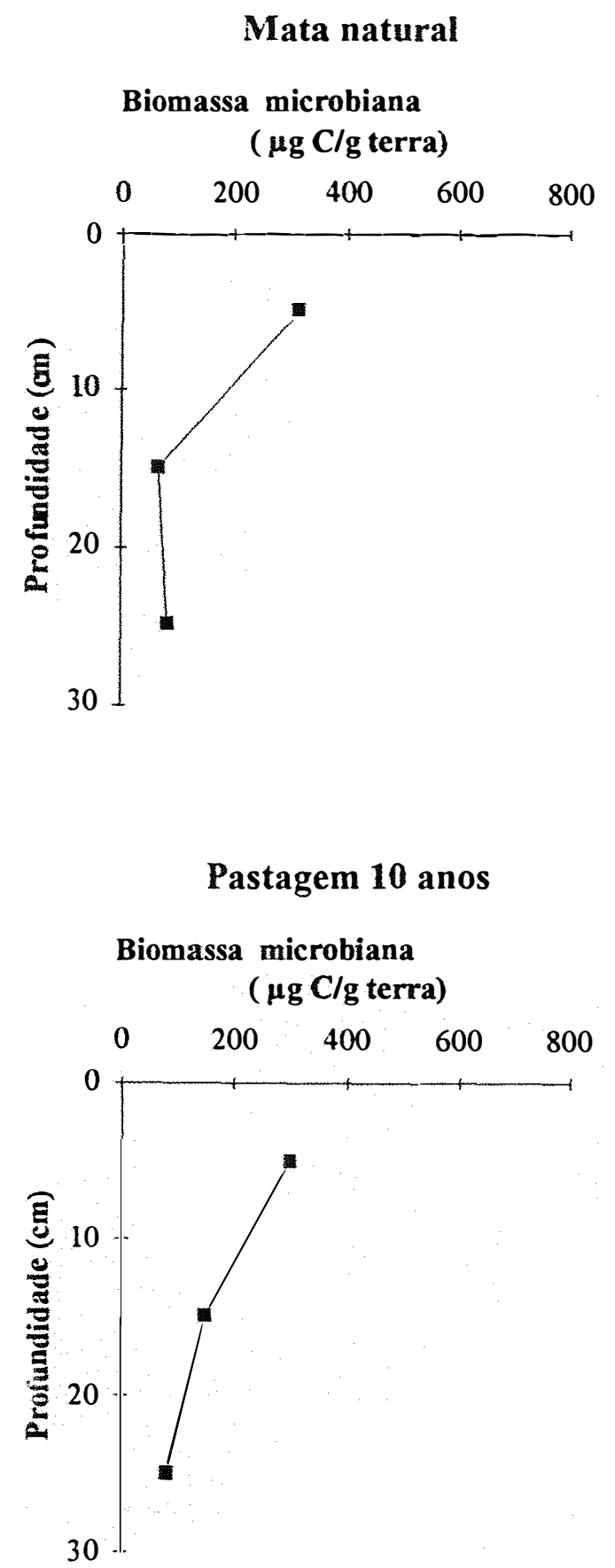

\section{Pastagem 4 anos}

Biomassa microbiana

( $\mu \mathrm{g} \mathrm{C/g} \mathrm{terra)}$

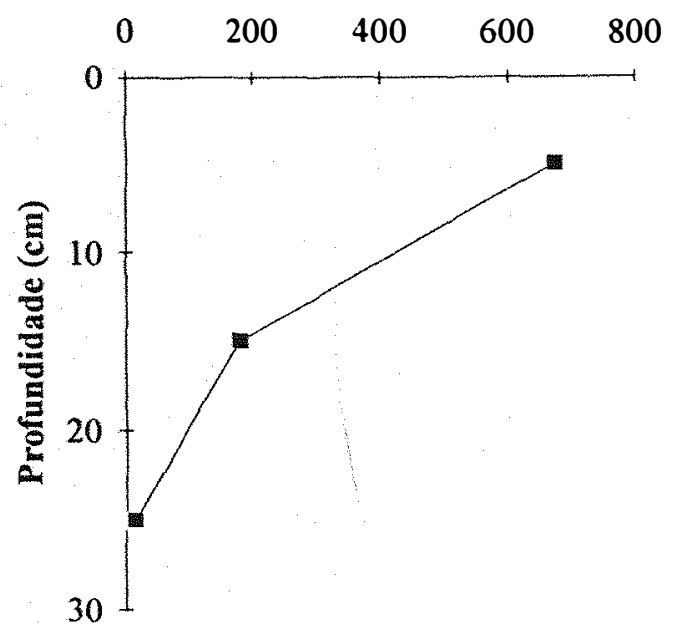

Pastagem 15 anos

\section{Biomassa microbiana}

( $\mu \mathrm{g} \mathrm{C/g} \mathrm{terra)}$

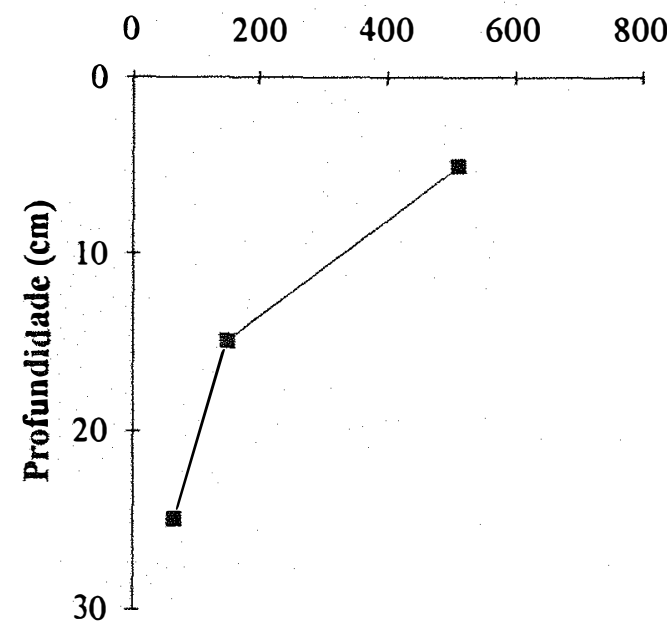

Figura 10 - Biomassa microbiana $C$ determinada pelo método FI. 
Tabela 08 - Biomassa microbiana C determinada pelo método da FumigaçãoExtração. Média de três repetições espaciais.

\begin{tabular}{|c|c|c|c|c|}
\hline \multirow[b]{2}{*}{ Profundidade } & \multicolumn{2}{|c|}{ C extraído } & \multirow{2}{*}{$\mathrm{Ce}^{\mathrm{I}}$} & \multirow{2}{*}{ Biomassa } \\
\hline & Fumigado & Testemunha & & \\
\hline $\mathbf{c m}$ & \multicolumn{4}{|c|}{ 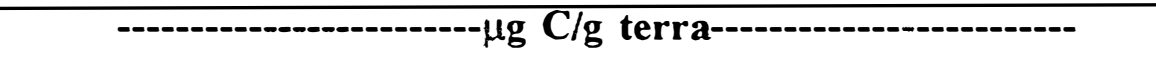 } \\
\hline \multicolumn{5}{|c|}{ Mata natural } \\
\hline $10-20$ & $692,56(76,7)$ & $592,79(61,3)$ & $99,77(23,0)$ & $302,67(79,1)$ \\
\hline $20-30$ & $624,49(58,7)$ & $589,99(73,6)$ & $34,49(29,3)$ & $104,53(89,0)$ \\
\hline $30-40^{2}$ & 501,47 & 468,11 & 33,36 & 101,09 \\
\hline $40-50^{2}$ & 353,46 & 331,98 & 21,48 & 65,11 \\
\hline \multicolumn{5}{|c|}{ Pastagem 4 anos } \\
\hline $0-10$ & $538,05(81,0)$ & $289,10(30,1)$ & $248,94(71,9)$ & $754,36(218,1)$ \\
\hline $10-20$ & $531,59(76,3)$ & $442,71(101,2)$ & $126,19(87,3)$ & $382,39(264,7)$ \\
\hline $20-30$ & $593,39(36,2)$ & $554,21(45,0)$ & $39,18(9,8)$ & $118,72(29,9)$ \\
\hline $30-40^{2}$ & 511,47 & 503,38 & 8,08 & 24,49 \\
\hline $40-50^{2}$ & 522,61 & 463,63 & 58,97 & 178,72 \\
\hline \multicolumn{5}{|c|}{ Pastagem 10 anos } \\
\hline 0-10 & $427,23(80,1)$ & $291,62(32,6)$ & $135,60(54,9)$ & $410,92(166,6)$ \\
\hline $10-20$ & $476,46(8,2)$ & $399,64(20,6)$ & $76,82(25,4)$ & $232,78(77,0)$ \\
\hline 20-30 & $513,20(55,1)$ & $479,34(51,1)$ & $33,86(24,4)$ & $102,61(74,2)$ \\
\hline $30-40^{2}$ & nd & nd & nd & nd \\
\hline $40-50^{2}$ & 362,40 & 356,79 & 5,61 & 17,00 \\
\hline \multicolumn{5}{|c|}{ Pastagem 15 anos } \\
\hline $0-10$ & $301,57(55,7)$ & $234,43(78,9)$ & $67,14(83,9)$ & $203,45(254,4)$ \\
\hline $10-20$ & $327,47(224,8)$ & $319,87(109,7)$ & $7.60(10,8)$ & $23,03(32,9)$ \\
\hline $20-30$ & $402,07(98,5)$ & $372,34(95,2)$ & $29,73(18,12)$ & $90,09(54,9)$ \\
\hline $30-40^{2}$ & 370,66 & 303,61 & 67,05 & 203,14 \\
\hline $40-50^{2}$ & 356,16 & 350,23 & 5,93 & 17,98 \\
\hline
\end{tabular}

Carbono extraidoda amostra fumigada menos Carbono extraido da amostra testemunha.

${ }^{2}$ somente uma repetị̧ão. nd = não determinado. ( ) desvio padrão. 


\section{Mata natural}

Biomassa microbiana

$$
\text { ( } \mu \mathrm{g} \mathrm{C/g} \mathrm{terra)}
$$

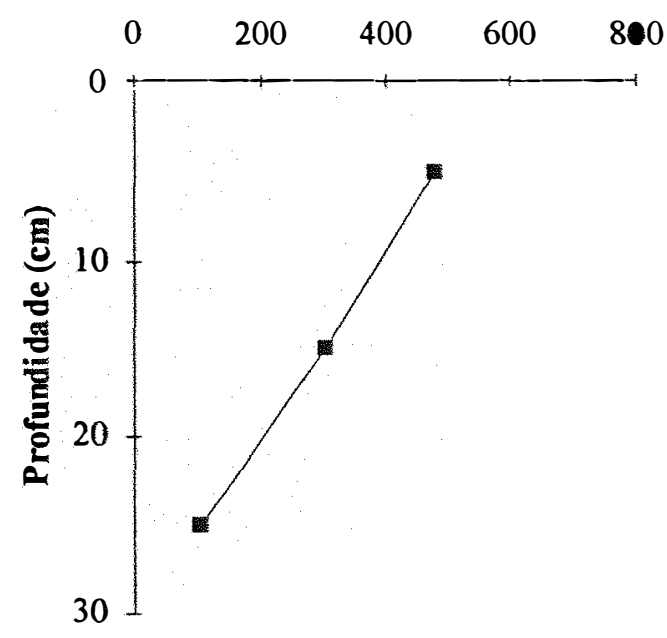

\section{Pastagem 10 anos}

Biomassa microbiana

$$
\text { ( } \mu \mathrm{g} \mathrm{C/g} \mathrm{terra)}
$$

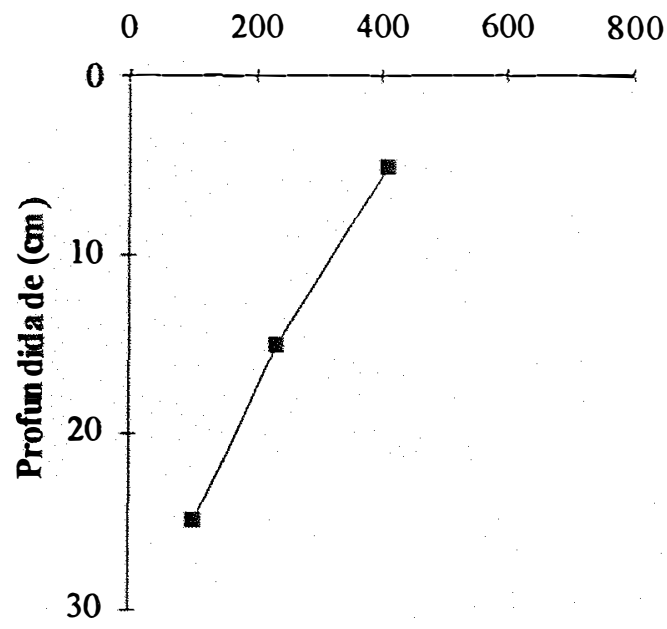

\section{Pastagem 4 anos}

Biomassa microbiana

( $\mu \mathrm{g} \mathrm{C/g} \mathrm{terra)}$

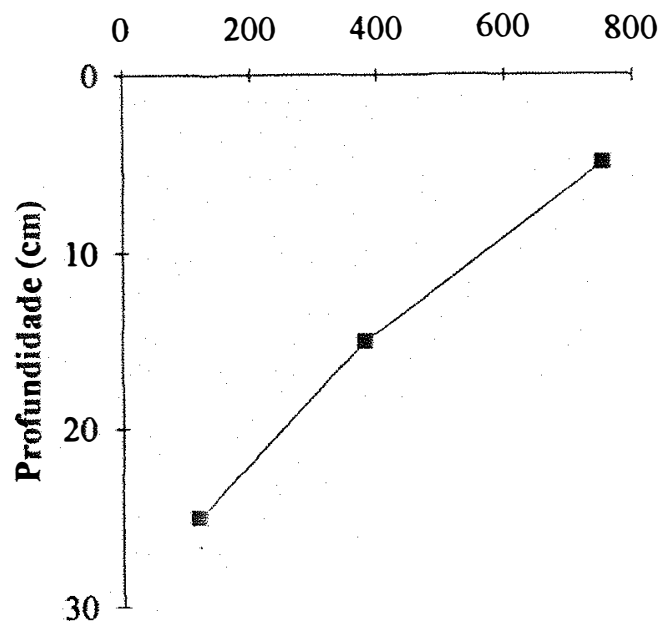

Pastagem 15 anos

\section{Biomassa microbiana}

( $\mu \mathrm{g} \mathrm{C} / \mathrm{g}$ terra)

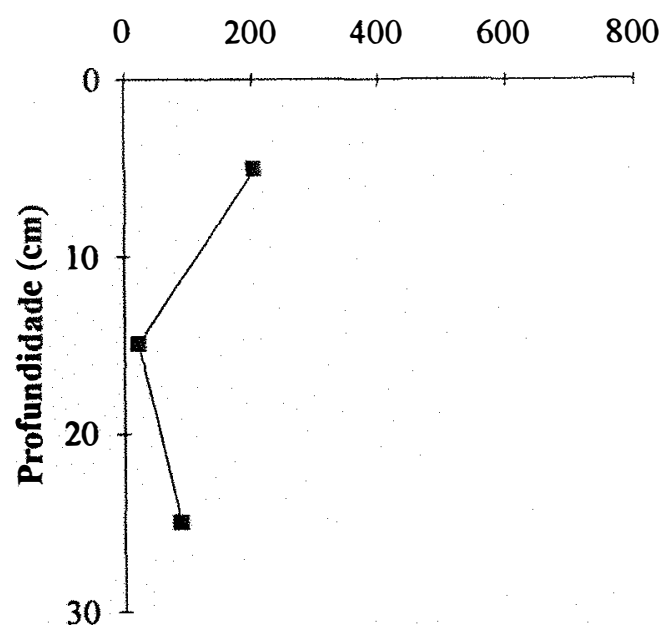

Figura 11 - Biomassa microbiana $C$ determinada pelo método $F E$. 
A equação foi calculada como: $y=2,59 x-61,29 \quad(r=0,93$ $\mathrm{P}<0,01$ ). Foram retirados as amostras de terra abaixo de $30 \mathrm{~cm}$ de profundidade por não apresentarem repetições espacias e as amostras das camadas $0-10$ e $10-20 \mathrm{~cm}$ da pastagem com 15 anos, uma vez que os resultados obtidos não observaram a mesma tendência que os das pastagens com 4 e 10 anos e os da mata natural. A correlação entre os métodos mostrou-se positiva.

Verificou-se que a biomassa microbiana concentrou-se nos primeiros $10 \mathrm{~cm}$ do solo, devido à grande disponibilidade de matéria orgânica facilmente decomponível presente nesta camada.

A pastagem com 4 anos, na camada superficial do solo, apresentou um aumento da biomassa microbiana de 58\% e $114 \%$, pelos métodos $\mathrm{FE}$ e FI, se comparada à mata natural. Isto deve-se à grande quantidade de raizes presentes (LUIZÃO et al.,1991) e a pouca compactação sofrida por este solo ocasionada pela a intensa movimentação dos rebanhos bovinos.

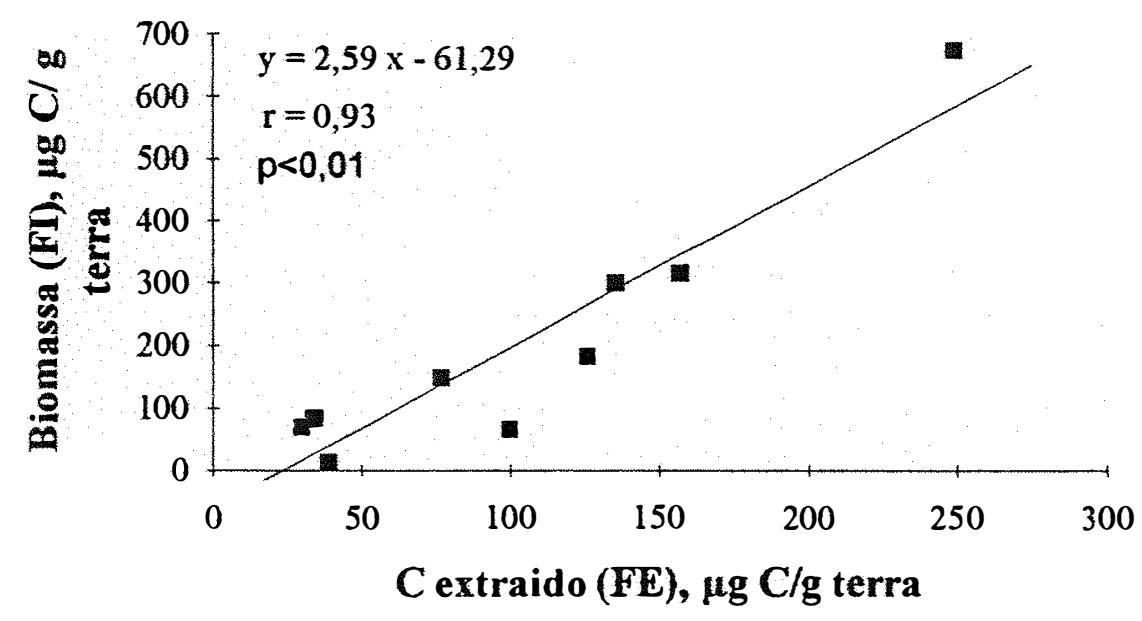

Figura 12 - Relação entre a biomassa microbiana C estimada pelo método da FI e o fluxo de carbono extraído pelo método da FE. 
$\mathrm{Na}$ área sob pastagem com 10 anos de implantação, houve uma diminuição de $13 \%$ pelo método $\mathrm{FE}$ e de $4,7 \%$ pelo método $\mathrm{FI}$. Contudo, a determinação da biomassa microbiana na área com pastagem de 15 anos apresentou resultados diferentes nos dois métodos utilizados; pelo método FI, a biomassa microbiana apresentou um aumento de $62 \%$ em relacão à mata natural, enquanto que, pelo método $\mathrm{FE}$, a biomassa microbiana sofreu uma redução de $57 \%$ em relação à mata, redução esta que está de acordo com trabalhos realizados por BONDE \& ROBERTSON (1991) e LUIZÃO et al. (1991), os quais registraram uma diminuição da biomassa microbiana a níveis iguais ou inferiores à metade dos valores encontrados na floresta. Esta diminuição seria devido às modificações causadas na estrutura física do solo devido à compactação do solo pelo intenso pisoteio da área.

\subsection{Estimativa da Biomassa Microbiana N.}

A biomassa microbiana $\mathrm{N}$ concentrou-se nos $10 \mathrm{~cm}$ superficiais do solo, correspondendo a $55,3 \% ; 54,9 \% ; 55,12 \%$ e $45,0 \%$ na mata natural e pastagens com 4,10 e 15 anos de implantação (Tabela 09 e Figura 13).

$\mathrm{Na}$ camada superficial do solo, a pastagem com 4 anos de implantação apresentou a maior biomassa microbiana encontrada, seguida pelas pastagens com 10 e 15 anos. Estes aumentos representaram cerca de $81,1 \%, 50,9 \%$ e $48,0 \%$ em relação à biomassa existente na mata. $\mathrm{Na}$ área sob mata natural, a biomassa microbiana sofreu uma redução de $55,0 \%$ na camada $10-20 \mathrm{~cm}$, enquanto que as reduções sofridas pelas pastagens com 
4,10 e 15 anos representaram $39,4 \% ; 36,5 \%$ e $41,6 \%$.

Tabela 09 - Biomassa microbiana $\mathbf{N}$ determinada pelo método da FumigaçãoExtração. Média de três repetições espaciais.

\begin{tabular}{|c|c|c|c|c|}
\hline \multirow[b]{2}{*}{ Profundidade } & \multicolumn{2}{|c|}{ N extraído } & \multirow{2}{*}{$\mathbf{N e}^{\mathbf{l}}$} & \multirow{2}{*}{ Biomassa } \\
\hline & Fumigado & Testemunha & & \\
\hline \multirow[t]{2}{*}{$\mathbf{c m}$} & \multicolumn{4}{|c|}{ 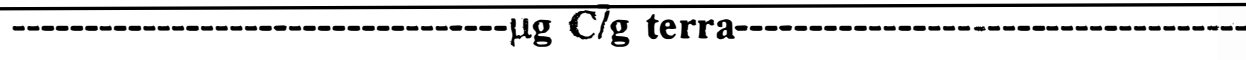 } \\
\hline & \multicolumn{3}{|c|}{ Mata natural } & \\
\hline 0-10 & $144,99(1,6)$ & $125,64(3,9)$ & $19,35(2,3)$ & $35,83(4,29)$ \\
\hline $10-20$ & $105,60(25,3)$ & $96,91(30,3)$ & $8,69(6,5)$ & $16,09(12,1)$ \\
\hline 20-30 & $85.48(18,6)$ & $78,55(17,8)$ & $6,94(3,29)$ & $12,85(6,09)$ \\
\hline $30-40^{2}$ & 58,45 & 57,83 & 0,62 & 1,15 \\
\hline \multirow[t]{2}{*}{$40-50^{2}$} & 48,73 & 47,45 & 1,28 & 2,37 \\
\hline & \multicolumn{3}{|c|}{ Pastagem 4 anos } & \\
\hline $0-10$ & $89,46(15,4)$ & $54,41(9,7)$ & $35,05(5,9)$ & $64,90(10,9)$ \\
\hline $10-20$ & $68,77(4,1)$ & $49,36(3,6)$ & $21,23(1,5)$ & $39,32(2,8)$ \\
\hline $20-30$ & $77,86(12,7)$ & $70,26(14,4)$ & $7,60(4,4)$ & $14,08(8,2)$ \\
\hline $30-40^{2}$ & 52,50 & 43,25 & 9,25 & 17,13 \\
\hline \multirow[t]{2}{*}{$40-50^{2}$} & 49,70 & 40,40 & 9,30 & 17,22 \\
\hline & \multicolumn{3}{|c|}{ Pastagem 10 anos } & \\
\hline 0-10 & $97,45(12,0)$ & $68,24(5,2)$ & $29,21(7,3)$ & $54,09(13,6)$ \\
\hline $10-20$ & $73,02(2,2)$ & $54,48(2,1)$ & $18,54(3,6)$ & $34,34(6,6)$ \\
\hline $20-30$ & $54,83(6,4)$ & $49,60(6,1)$ & $5,23(1,61)$ & $9,69(2.98)$ \\
\hline $30-40^{2}$ & 49,84 & 45,72 & 4,12 & 7,62 \\
\hline \multirow[t]{2}{*}{$40-50^{2}$} & 50,72 & 33,22 & 17,50 & 32,41 \\
\hline & \multicolumn{3}{|c|}{ Pastagem 15 anos } & \\
\hline 0-10 & $121,53(23,6)$ & $92,88 \quad(14,53)$ & $28,65(9,14)$ & $53,06(16,92)$ \\
\hline $10-20$ & $69,41(17,94)$ & $52,67(15,2)$ & $16,74(5,19)$ & $31,00(9,61)$ \\
\hline 20-30 & $69,91(26,12)$ & $51,61(16,4)$ & $18,30(9,72)$ & $33,89(18,0)$ \\
\hline $30-40^{2}$ & 41,34 & 33,09 & 8,25 & 15,28 \\
\hline $40-50^{2}$ & 40,21 & 32,50 & 7,71 & 14,28 \\
\hline
\end{tabular}

${ }^{1}$ Nitrogênio extraído da amostra fumigada menos Nitrogênio extraído da amostra testemunha

2 somente uma repetição espacial. () desvio padrão. 

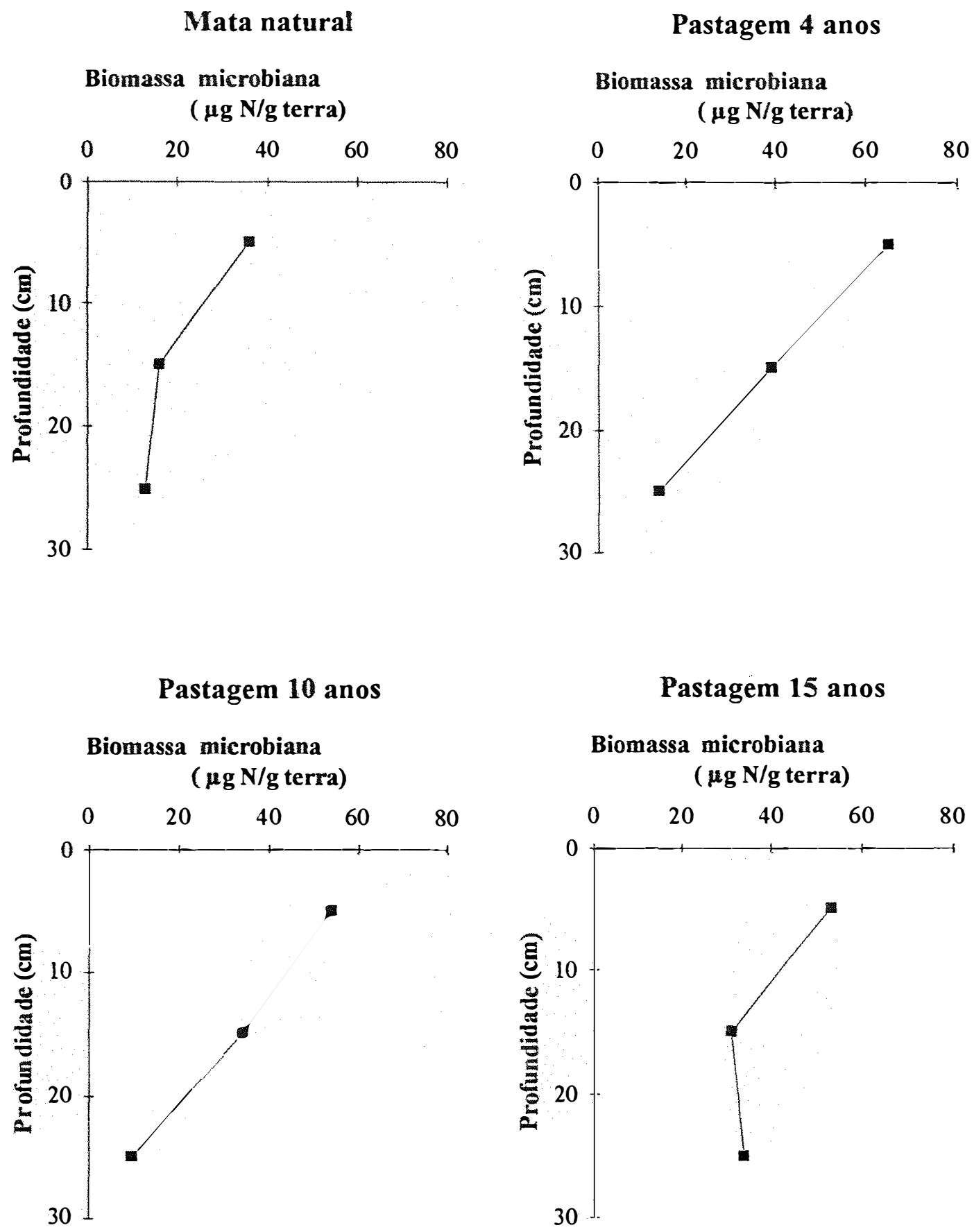

Figura 13 - Biomassa microbiana $\mathbf{N}$ determinada pelo método $\mathrm{FE}$. 
De um modo geral, à medida que a profundidade do solo aumentou, a biomassa microbiana tornou-se menor. Porém a pastagem com 15 anos de implantação mostrou um aumento de $9,32 \%$ na camada $20-30 \mathrm{~cm}$.

Os dados obtidos com a determinação da biomassa microbiana $\mathrm{N}$ mostraram a mesma tendência que os apresentados pela biomassa microbiana $\mathrm{C}$ pelo método $\mathrm{FE}$, ou seja, nos primeiros anos de cultivo a biomassa microbiana foi maior que a biomassa da floresta e, à medida que a pastagem tornou-se mais velha, a biomassa microbiana diminuiu.

\subsection{Relação entre Carbono Total, Nitrogênio Total e Biomassa microbiana.}

Os resutados apresentados na Tabela 10 indicam a relação existente entre a biomassa microbiana $\mathrm{C}$ e $\mathrm{N}$ e os teores de carbono e nitrogênio do solo.

Nos primeiros $20 \mathrm{~cm}$ superficiais do solo, a quantidade de carbono imobilizado como biomassa microbiana foi maior na área sob pastagem com 4 anos e as pastagens com 10 e 15 anos mostraram valores menores aos da mata natural, sendo que a pastagem com 15 anos apresentou os menores valores.

Notou-se que houve um aumento progressivo da relação até a camada $20 \mathrm{~cm}$ para as áreas de mata natural e pastagens com 4 e 10 anos, que também foi verificado por CERRI et al.(1985b) até a camada de $15 \mathrm{~cm}$. A área sob pastagem com 15 anos mostrou uma diminuição da 
relação na camada de $20 \mathrm{~cm}$.

Estes resultados revelam que a relação entre a biomassa microbiana e o carbono do solo é inferior à encontrada por JENKINSON \& POWLSON,(1976) e OADES \& JENKINSON (1979) para outros solos.

Tabela 10 - Relaçao entre carbono total, nitrogênio total e biomassa microbiana C e $\mathbf{N}$ determinadas pelo método $\mathbf{F E}$.

\begin{tabular}{|c|c|c|c|}
\hline Área & Profundidade & $\mathrm{CBM} / \mathrm{Ct} \times 100$ & NBM/Nt $\times 100$ \\
\hline & $\mathbf{c m}$ & \multicolumn{2}{|c|}{ - } \\
\hline \multirow[t]{5}{*}{ Mata natural } & $0-10$ & 1,9 & 1,7 \\
\hline & $0-20$ & 2,0 & 1,6 \\
\hline & $0-30$ & 1,8 & 1,6 \\
\hline & $0-40$ & 1,7 & 1,4 \\
\hline & $0-50$ & 1,7 & 1,3 \\
\hline \multirow[t]{5}{*}{ Pastagem 4 anos } & $0-10$ & 2,7 & 2,3 \\
\hline & $0-20$ & 2,8 & 2,6 \\
\hline & $0-30$ & 2,4 & 2,4 \\
\hline & $0-40$ & 2,1 & 2,4 \\
\hline & $0-50$ & 2,2 & 2,4 \\
\hline \multirow[t]{5}{*}{ Pastagem 10 anos } & $0-10$ & 1,7 & 3,0 \\
\hline & $0-20$ & 1,8 & 3,1 \\
\hline & $0-30$ & 1,6 & 2,8 \\
\hline & $0-40$ & nd & 2,6 \\
\hline & $0-50$ & nd & 3,0 \\
\hline \multirow[t]{5}{*}{ Pastagem 15 anos } & $0-10$ & 0,7 & 2,4 \\
\hline & $0-20$ & 0,5 & 2,5 \\
\hline & $0-30$ & 0,6 & 2,9 \\
\hline & $30-40$ & 0,8 & 2,8 \\
\hline & $40-50$ & 0,8 & 2,7 \\
\hline
\end{tabular}


O nitrogênio imobilizado como biomassa microbiana foi maior nas áreas de pastagens do que sob mata natural.

A pastagem com 10 anos apresentou, nos $20 \mathrm{~cm}$ superficiais do solo, a maior relação, com cerca de $3 \%$ do nitrogênio imobilizado na biomassa.

As áreas sob pastagens apresentaram um aumento progressivo da relação até $20 \mathrm{~cm}$ de profundidade. Este aumento foi verificado até $30 \mathrm{~cm}$ para a pastagem com 15 anos.

$\mathrm{Na}$ área sob mata natural, a maior relação encontrada foi na camada de 10 centímetros e diminuiu a medida que a profundidade aumentou.

Deste modo, em áreas sob pastagens, a biomassa microbiana representa um importante compartimento de reserva de nitrogênio e impede a perda deste nutriente através dos processos de lixiviação. 


\section{CONCLUSÕES}

A partir dos resultados apresentados sobre o conteúdo de carbono, nitrogênio e biomassa microbiana em áreas onde houve a transformação da floresta nativa em pastagens pode-se concluir que:

1. A transformação de áreas sob mata natural em pastagens levou, ao longo do tempo de cultivo, a um aumento no estoque de carbono destas áreas e a introdução das pastagens, em áreas anteriormente cultivadas com milho ocasionou um aumento no conteúdo de carbono do solo à níveis iguais ou superiores ao da vegetação nativa. Com o desmatamento houve uma diminuição progressiva do carbono remanescente da floresta e um aumento do carbono proveniente da pastagem, ao longo do tempo de cultivo.

2. Com a introdução da pastagem houve um aumento progressivo da contituição isotópica da matéria orgânica do solo ao longo do tempo de cultivo, causado pela entrada de material vegetal com ciclo fotossintético $\mathrm{C}_{4}$, sendo que a camada superficial $(0-10 \mathrm{~cm})$ apresentou as maiores diferenças. 
3. $\mathrm{Na}$ área sob mata natural o carbono total era composto por $23,2 \%$ sob a forma biodegradável e $76,7 \%$ sob a forma estável e após 15 anos de implantação da pastagem o carbono biodegradável passou a representar $11,6 \%$ do carbono da floresta enquanto que o estável $88 \%$, deste modo, como a matéria orgânica dos solos sob pastagens é contituída basicamente de carbono estável, o carbono introduzido pela pastagem seria o principal responsável pelos processos biológicos do solo.

4. O conteúdo de nitrogênio do solo aumento nas pastagens de 4 e 15 anos em relação à mata natural e diminuiu na pastagem de 10 anos. Estes aumentos são devidos, provavelmente, à fixação do nitrogênio pelos microrganismos do solo.

5. Verificou-se uma correlação positiva entre os métodos FI e FE para a determinação da biomassa microbiana $C$, contudo os valores encontrados pelo método FE foram superiores ao encontrado pelo método FI.

6. A biomassa microbiana concentrou-se na camada superficial, onde a disponibilidade de matéria orgânica é maior e a medida que o tempo de cultivo aumentou, a biomassa microbiana decresceu, pois o solo sofreu mudanças nas suas características físicas causadas pela compactação do solo através de intenso pastoreio.

7. O nitrogênio imobilizado como biomassa microbiana em relação ao nitrogênio total do solo foi maior nas áreas sob pastagens, quando comparado com a mata natural, representando, deste modo, um importante compartimento de reserva de nitrogênio orgânico. 


\section{LITERATURA CITADA.}

ANDERSON,T.H. \& DOMSCH,K.H..A physiological method for the quantitative measurement of microbial biomass in soils. Soil Biol. Biochem. Oxford.10:215-221.1978.

BAUER, A. \& BLACK, A.L.. Carbon nitrogen and bulk density comparison in two cropland tillage systems after 25 years and virgin grasslands. Soil Science Society of America Journal 45:1166-1170. 1981 .

BLAKE, G.R. \& HARTGE, K.H.. Bulk density. IN: KLUTE, A. ed. Methods of soil analysis: part I. physical and mineralogical methods.2ed. Madison, ASA, p. 363-375. 1986.

BOHN, H.L.. Estimate of organic carbon in wold soils. Soil Sci. Soc. Am. J. 40:468-470.1976.

BONDE, T.A. \& ROBERTSON, K..Soil organic nitrogen dynamics: changes after clear-felling and cultivation of a tropical rainflorest soil. IN: BONDE, T.A.. Size and dynamics of active organic matter fraction as 
influenced by soil management. Linkoping Studies in Arts and Science 63. 1991.

BONDE, T.A.; ROSSWALL, T.; VITÓRIA, R.L.The dynamics of soil organic matter and soil microbial biomass following clear-felling and cropping of a tropical rainforest in the central Amazon. Linköping Studies in Arts and Science. 63. Linköping, Sweden.1992.

BOTTNER, P.; SALLIH, Z.; BILLES,G.. Roat activity and carbon metabolism in soil.Biol. Fertil. Soil 7:71-81. 1988.

BREMNER, J.M. \& SHAW, K.. Denitrification in soil. I.Methods of Investigation. Agric.Sci.51:22-39.1958

BROOKES, P.C.; LANDMAN,A.; PRUDEN,G.; JENKINSON,D.S.. Chloroform fumigation and the realese of soil nitrogen: a rapid direct extraction method to measure microbial nitrogen. Soil Biol. Biochem. 17:837-842. 1985.

BUSCHBACHER, R.; UHL, C.; SERRÃO, E.A.S. Abandoned pastures in eastein Amazonia. II Nutrient stocks in the soil and vegetation. Journal of Ecology.76:692-699. 1988.

CERRI, C.C.; FELLER, C.; BALESDENT,J.; VITÓRIA， R.L.; PLENECASSAGNE, A. Aplication du traçage isotopique naturel en ${ }^{13} \mathrm{C}$, à l'étude de la dynamique de la matiére organique dans les sols. C.R.Acad.Sc. Paris, t300, série II, 9.1985a.

CERRI, C. C.; VOLKOFF, B.; EDUARDO, B. P.. Efeito do desmatamento sobre a biomassa microbiana em Latossoloamarelo da Amazônia. R. bras. Ci. Solo 9(1):1-4. 1985b.

CERRI, C. C.. Dinânica da matéria orgânica do solo no agrossistema canade-ácúcar. Piracicaba, 1986. 197p (Livre-docência-ESALQ/USP). 
CERRI, C.C.. Dinânica da matéria orgânica em solos de pastagens. IN: SIMPÓSIO SOBRE ECOSSISTEMA DE PASTAGENS. Anais. p135147. 1989.

CERRI, C.C. \& ANDREUX, F.G.. Changes in organic carbon content in oxisols cultivated with sugar cane and pastures based on ${ }^{13} \mathrm{C}$ atural abundance measurement. IN: INTERNATIONAL CONGRESS OF SOIL SCIENCE, 14; Kyoto,ICSS, p98-103. 1990.

CERRI, C.C.; FELLER, C.; CHAUVEL, A. Evolução das principais propriedades de um latossolo vermelho escuro após desmatamento e cultivo por doze e cinquenta anos com cana-de-açúcar. Pedologia. 26(1):37-50.1991.

CERRI, C.C.\& MORAES, J.F.L..Consequências do uso e manejo do solo no teor de matéria orgânica. IN: ENCONTRO SOBRE MATÉRIA ORGÂNICA DO SOLO - PROBLEMAS E SOLUÇÕES. Anais. Botucatu. p25-36. 1992.

CHAUVEL, A.. Os latossolos amarelos, álicos, argilosos, dentro dos ecossistemas das bacias experimentais do IMPA e da região vizinha. Acta Amaz. Manaus. supl. 12(3):47-60. 1982.

CHAUVEL, A.; GRIMALDI, M.; TESSLER, D. Changes in soil proe-space distribuition following deforestation and revegetation: an example from the Central Amazon Basin. Forest Ecology and Mamagement 38:259-271. 1991.

CHONÉ, T.; ANDREUX, F.; CORREA, J. C.; VOLKOFF, B.; CERRI,C.C.. Changes in organic matter in an oxisol from the central Amazonian forest during eigth-yeurs as pasture, determined by ${ }^{13} \mathrm{C}$ isotopic composition. IN. J. BERTHELIN (Ed). Diversity of 
Environmemtal Biogeochemistry. Elsevier.397-405. 1991.

DESJARDINS, T.; CHONÉ, T; ANDREUX, F.. Evolution du carbone organique d'origine forestière et graminéennedans des sols sous prairies cultivées d'Amazonie Centrale et Orientale. J.Scientifique PIRAT Strasbourg. 25 Mars. 1991

FALESI, I.C. Ecossistema de Pastagem cultivada na Amazônia Brasileira. Boletim Técnico do CPATU/EMBRABA. nº 1. Belém. 1976.

FEARNSIDE, P.M.. Human carrying capacity of the brazilian rainforest. New York. Columbia University Press.1989.

GUPTA, V. V. S. R. \& GERMIDA, J. J.. Distribuition of microbial biomass and its activity in different soil aggregate size classes as affected by cultivation. Soil Biol. Biochem. 20:777-785.1988.

HERRERA, R.; JORDAN, C.F.; KLINGE, H.; MEDINA, E.. Amazon ecosystems. Their structure and functioning with particular emphasis on nutrients. Interciência.3(4):223-232. 1978.

HOUGHTON ,R.A.; HOBBIG, J.E.; MELILLO, J.M; MOORE,B.; PETERSON,B.J.; SHAVER,G.R.; WOODWELL,G.M.. Changes in the carbon content of terrestrial biota and soils between 1860 and 1980: a net release of $\mathrm{CO}_{2}$ to the atmosphere. Ecological Monographs. New Hampshire, 53(3):235-62. 1983.

HOUGHTON, R.A.; BOONE, R.D.; MELILlO,J.M.; PALM,C.A.; WOODWELL,G.M.; MYERS,N.; MOORE,B.; SKOLE,D.L.. Net flux carbon dioxide from tropical forest in 1980. Nature 316:617-620. 1985. JENKINSON,D.S. \& POWLSON, D.S.. The effects of biocidal treatments on metabolism in soil. V. A method for mearuring soil biomass.Soil Biol.Biochem. 8:209- 213.1976. 
JENKINSON, D.S. \& LADD,J.N.. Microbial biomass in soil. Measurement and turnover. IN. Soil Biochemistry (E.A.Paul and J.N.Ladd, Eds) Dekker,New York, p415-471.1981.

KLAKE, G.R. \& HARTGE, K.H. Bulk density. IN: KLUTE, A. ed. Methods of soil analysis: part I. phisical and mineralogical methods 2ed. Madison, ASA, 1986. p363-75.

KLEMEDTSSON, L.; BERG, P.; CLARHOLM, M.; SCHNURER,L.. Microbial nitrogen transformation in the root enviroment of barley. Soil Biol. Biochem. 19:551-558. 1987.

LUIZÃO, F.J. \& SCHUBART,H.O.R.. Litter production and decomposition in a terra firme fores of Central Amazônia. Experientia 43:259-265. 1987.

LUIZÃO, R.C.. Variações temporais da biomassa microbiana e aspectos da ciclagem do nutriente em solos de floresta natural e de sistemas manejados na Amazônia Central. Dissertação de Mestrado. IMPA/FVA. 67p. 1989.

LUIZÃO, R.C.; CAMPISTA, D.; COSTA, E.S. Efeito da idade e do manejo das pastagens da Amazônia Central sobre a biomassa microbiana e suas atividades no solo. Anais do II SIMPÓSIO BRASILEIRO SOBRE MICROBIOLOGIA DO SOLO. São Paulo. 1991. p.49

MANN, L. K.. Changes in soil carbon storaged after cultivation. Soil Sci.,14(5):279-295. 1986.

MARTELL,Y.A. \& PAUL,E.A.. Effects of cultivation on the organic matter of grassland soils as determined by fractionation and radiocarbon dating. Canadian J.Soil Science, 54:419-426. 1974.

MARTINS, P.F. da S. \& CERRI,C.C. O solo de um ecossistema natural de 
floresta localizado na Amazônia Oriental.I. Caracterização química e física. IN: SIMPÓSIO DOTRÓPICO ÚMIDO,1. Belém, 1984. Anais. Belém. EMBRAPA-CPATU. v.1 p 271-86. (EMBRAPA-CEPATU. Documentos 36). 1986.

MARTINS, P.F. da S.. Propriedades de solos sob floresta natural e sua alteracão em consequência do desmatamento e cultivo, na Amazônia Oriental. Tese de Doutoramento. ESALQ/USP. Piracicaba,SP. Brasil.1987.

MARTINS, P.F. da S.; VOLKOFF, B. CERRI, C.C.; ANDREUX, F.. Consequências do cultivo e do pousio sobre a matéria orgânica do solo sob floresta natural na Amazônia Oriental. Acta Amazônica 20:19-28. 1990a.

MARTINS, P.F. da S.; CERRI, C.; VOLKOFF, B.;ANDREUX, F.. Efeito do desmatamneto e do cultivo sobre características físicas e químicas do solo sob floresta natural na Amazônia Oriental. Rev. IG. São Paulo. 810, $11(1): 21-33$. 1990b.

MORAES, J.F.L.. Conteúdos de carbono e nitrogênio e tipologia de horizontes nos solos da Bacia Amazônica. Dissertação de Mestrado. CENA/USP. Piracicaba. 84p. 1991.

NEILL, C; MORAES, J.L.; MELILLO, J.M.; CERRI, C.C.; STEUDLER,P.A.; VOLKOFF,B.. Soil responses to forest-to-pasture conversion in the western Brazilian Amazom Basin. (submetido) J. Soil Sci. 1993.

OADES, J.M. \& JENKINSON, D.S. Adenosine triphosphate content of the soil microbial biomass. Soil Biol.Biochem. Oxford. 11:201-204. 1979. 
OCIO, J.A. \& BROOKES,P.C. An evaluation of methods for measuring the microbial biomass in soils following recent addition of wheat straw and the caracterization of the biomass that develops. Soil Biol.Biochem. Oxford. 22:685-694. 1990

ORJUELA, H.B. El suelo: una vision sobre sus componentes biorgánicos. Pasto.Universidad de Marinõ. 447p. 1989.

PFENNING,L.; EDUARDO,B. de P.; CERRI,C.C.. Os métodos da fumigação-incubação e fumigação-extração na estimativa da biomassa microbiana de solos da Amazônia. R.bras.Ci. Solo, 16:31-38. 1992.

PICCOLO, M. \& NEILL,C. ${ }^{15} \mathrm{~N}$ natural abundance in soils along forest-topasture chronosequences in the Brazilian Basin Amazon. 1993 (submetido).

POST,W.M.; EMANUEL,W.R.; ZINKE,P.J.; STANGENBERGER, A.G. Soil carbon pools and wold life zones. Nature. 298:156-159. 1982

POWISON, D.S.; BROOKES, P.C.; CHRISTENSEN, B.T.. Measurement of soil microbial biomass provides an early indication of changes in total soil organic matter due to straw incorporation. Soil Biol. \& Biochem. 19(2):159-164. 1987.

RODRIGUES, E.F. da G. Biomassa-C microbiana de solos de Itaguaí: Comparação entre os métodos da fumigação- incubação e fumigaçãoextração. Dissertação de Mestrado. UFRG. Rio de Janeiro. 108 p. 1992

ROSS,D.J.; TATE,K.R.; CAIRNS, A.; PANSIER,E.A.. Microbial biomass estimation in soil from tussock grass lands by three biochemical procedures. Soil Biol. Biochem. Oxford. 12:375-383. 1980 
ROSS, D.J. Soil microbial biomass estimated by the fumigation-incubation procedure: seasonal fluctuations and influence of soil moisture content. Soil Biol.Biochem. Oxford. 19:397-404. 1987

SCHLESINGER,W.H. Carbon balance in terrestrial detritus Annual Rev. Ecol. and Syst. Palo Alto. 8:51-81. 1977

SPARLING, C.P. \& WEST, A.W. Importance of soil water content when estimating soil microbial $\mathrm{C}, \mathrm{N}$ and $\mathrm{P}$ by the fumigation-extraction method. Soil Biol. Biochem. Oxford. 21:245-253. 1989

SPARLING, G.P. Soil biomass evauatin.IN: Pacificland workshop on the establishment of soil management esperients on sloping lans. pp 163184. IBSRAM TECHINICAL NOTES 4. IBSRAM, Bangkok, 1990. SRIVASTAVA, S.C. \& SINGH, J.S.. Effect of cultivation on microbial biomass $\mathrm{C}$ and $\mathrm{N}$ of dry tropical forest soil. Biology and Fertility of Soils. 8:343-348. 1989.

TEIXEIRA, L.B. \& BASTOS, J.B. Matéria orgânica nos ecossistemas de floresta primária e pastagens na Amazônia Central. Boletim de Pesquisa 99 (EMBRAPA-CEPATU) Belém. 26p 1989

VANCE, E.D.; BROOKES,P.C.; JENKINSON,D.S.. An extraction method for measurement soil microbial biomass C. Soil Biol. Biochem. 19:703707. 1987.

VIEIRA,L.S. \& SANTOS, P.C.T.C..Amazônia. Seus solos e outros recursos naturais. São Paulo. Ed. Agronômica Ceres. p416 1987.

WOODWELL,G.M.; WITTAKER,R.H.; REINERS,W.A. The biota and the wold carbon budget. Science. 199:144-146. 1978 